\title{
PERNIKAHAN DENGAN WALI MUHAKKAM (Studi tentang Implikasi dan Persepsi Ulama di Kota Banjarmasin)
}

\author{
Abdul Kadir Syukur \\ Fakultas Syariah dan Ekonomi Islam IAIN Antasari, Jl. Jenderal Ahmad Yani Km 4,5 Banjarmasin \\ E-mail: abdkadirsyukuru01@gmail.com
}

\begin{abstract}
Marriage ideally using guardian nasab who still have blood relations with the bride. But there are many obstacles that cause the marriage cannot use the guardian nasab. In that situation, the guardian is replaced by the magistrate guardian. But some people want to take the easy path by treat Ulema, religious teacher, or certain figure as guardian Mubakkam. Basically, they are not entitled to be the marriage guardian, but this marriage practices are still occured, including in Banjarmasin. Is paper examines the issues of guardian nasab and mubakkam in the marriage. This paper results indicate that the reasons of using guardian mubakkam in marriage are because of the reluctance to deal with magistrate guardian and the desire to take the easy path in marriage. In the opinion of Ulama, that marriage is not valid because there is still a magistrate guardian authorized. Besides, that marriage causes a lot of disadvantage, especially for the wife. It is because the absence of legal force (marriage certificate), the difficulty to sue the rights of wife and child, and the difficulty to have a birth certificate.
\end{abstract}

Abstrak: Pernikahan idealnya menggunakan wali nasab, yaitu wali yang masih ada hubungan darah yang dekat dengan mempelai perempuan. Tetapi tidak jarang terjadi ada berbagai halangan yang berakibat pernikahan tidak bisa menggunakan wali nasab. Dalam kondisi demikian, wali hakimlah yang berperan. Namun sebagian masyarakat mengambil jalan pintas, dengan mengangkat ulama, guru agama atau tokoh tertentu sebagai wali yang biasa disebut dengan wali muhakkam. Mereka ini pada dasarnya tidak berhak menjadi wali, namun praktik pernikahan dengan wali muhakkam ini masih saja terjadi, termasuk di Kota Banjarmasin. Tulisan ini mengkaji persoalan wali dan wali muhakkam dalam pernikahan. Hasil penelitian menunjukkan bahwa pernikahan dengan wali muhakkam terjadi karena calon suami istri terhalang menikah dengan wali nasab, enggan berurusan dengan wali hakim dan ingin mengambil jalan mudah dalam melangsungkan pernikahan. Dalam pandangan para ulama pernikahan demikian tidak sah karena masih ada wali hakim yang berwenang, dan pernikahan demikian menimbulkan banyak kerugian terutama bagi istri karena ketiadaan kekuatan hukum (buku nikah), kesulitan dalam menuntut hak istri dan anak serta bagi anak karena akan kesulitan dalam mengurus akta kelahiran.

Kata kunci: Pernikahan, Wali, Wali Mubakkam.

\section{Pendahuluan}

Salah satu naluri, instink atau gharizah manusia adalah melakukan perkawinan (gharizah jinsiyah) guna menyalurkan kebutuhan biologis sekaligus melahirkan keturunan untuk kesinambungan manusia dari satu generasi ke generasi berikutnya. Kawin merupakan jalan alami yang paling baik, sehat dan sesuai untuk menyalurkan dan memuaskan naluri seks tersebut, sehingga seseorang menjadi tenang dan terhindar melakukan perbuatan haram. ${ }^{1}$

1 Al-Syaikh Sayyid Sabiq, Fiqh al-Sunnah, Jilid II, (Beirut: Dar al-Fikr, 1403 H), hlm. 10.
Allah Swt mensyariatkan perkawinan sebagai sarana manusia untuk menyalurkan kebutuhan biologisnya tersebut, dan untuk keperluan tersebut Allah telah menciptakan manusia berpasanganpasangan, ada pria yang kelak menjadi suami dan ada wanita yang akan menjadi istri. Di dalam Alquran dan hadis begitu banyak ayat yang berkenaan dengan perkawinan tersebut, ${ }^{2}$ begitu

2 Di antara ayat Alquran tetang perkawinan adalah QS al-Nisa ayat 1 , al-Ra'ad ayat 38 , al-Nahl ayat 72 , alRuum ayat 21, al-Nur ayat 32, al- Zariyaat ayat 49, Yasin ayat 36, dan al-Hujurat ayat 13. 
juga dengan hadis Nabi banyak sekali yang menekankan perkawinan. ${ }^{3}$

Perkawinan yang disyariatkan dalam Islam bersifat ibadah, bukan sebagai sarana untuk melampaskan hawa nafsu seksual saja. Oleh karena itu ikatan perkawinan merupakan ikatan yang sangat kuat dan mengandung tujuan-tujuan luhur. Di dalam pasal 2-3 Kompilasi Hukum Islam (KHI) dinyatakan, perkawinan menurut hukum Islam adalah pernikahan, yaitu akad yang kuat (mitsaqan gholiidhan) untuk menaati perintah Allah dan melaksanakannya merupakan ibadah. Perkawinan bertujuan untuk mewujudkan kehidupan rumah tangga yang sakinah, mawaddah dan rahmah. ${ }^{4}$

Sebagai pertanda kuatnya ikatan perkawinn dan untuk menjamin terwujudnya tujuan luhur perkawinan, maka sejak awal tata cara perkawinan sudah diatur dengan rukun dan syarat tertentu tertentu. Rukun nikah itu sendiri ada lima, yaitu adanya calon sami, calon istri, wali nikah, dua orang saksi dan ijab qabul. ${ }^{5}$ Salah satu dari rukun nikah tersebut, yaitu wali merupakan hal yang sangat penting dan menentukan sah tidaknya suatu perkawinan. Hal ini tercermin dari hadis Rasulullah Saw, yang artinya: Dari Abi Musa bahwasanya Nabi Sw bersabda: Tidak ada nikeah kecualinya dengan adanya wali (HR. Abi Daud). ${ }^{6}$

Hadis senada berbunyi yang artinya: Dari Aisyah berkata; Bersabda Rasulullah Saw: Siapa saja wanita yang dinikahkan dengan tanpa seizin walinya, maka nikahnya batal (beliau mengulanginya tiga kali). Jika lelakinya telah menyetubuhinya, maka ia berhak atas maharnya, karena ia telah menghalalkan kehormatannya. Jika pihak wali enggan menikahkan, maka hakimlah yang bertindak menjadi wali bagi seseorang yang tidak ada walinya (HR Abi Daud). ${ }^{7}$

3 Al Imam Abi Abdillah Muhammad bin Ismail bin Ibrahim al-Bukhari, Shabih al-Bukhari, Jilid III, Juz 6, (Beirut: Dar al-Fikr, $1401 \mathrm{H}$ ), hlm. 116. Lihat pula alShan'ani, Subul al-Salam, Jilid II, (Beirut: Dar al-Fikr, 1412 H), hlm. 109-10.

4 Adurrahman, Kompilasi Hukum Islam di Indonesia, (Jakarta: Akademika Pressindo, 1992), hlm. 114.

5 HAS. Alhamdani, Risalah Nikah, (Jakarta: Pustaka Amani, 1989), hlm. 30.

6 Al Imam Abi Daud Sulaiman ibn all-Asy'ats al-Sijistani, Sunan Abi Daud, Jilid 2, (Surabaya: Maktabah Dahlan, tth), hlm. 229.

7 Ibid.
Persoalan wali dalam hukum perkawinan Islam sangat penting dan menentukan keabsahan perkawinan itu sendiri. Namun wali di sini tidaklah bersifat kaku. Kalau tidak ada wali nasab, yaitu orang tua atau keluarga yang bersangkutan, atau wali nasabnya enggan menikahkan (wal adhal), maka ia berhak untuk menikah dengan menggunakan wali hakim. Pasal 23 ayat (1) dan (2) KHI menyatakan, wali hakim baru dapat bertindak sebagai wali nikah apabila wali nasab tidak ada atau tidak mungkin menghadirkannya atau tidak diketahui tempat tinggalnya atau ghaib atau adhal atau enggan. Dalam hal wali adhal atau enggan maka wali hakim baru dapat bertidak sebagai wali nikah setelah ada putusan Pengadilan Agama tentang wali tersebut. ${ }^{8}$

Di samping wali hakim, dalam praktik perkawinan bawah tangan yang terjadi di masyarakat dikenal pula wali hakim bawah tangan/tidak resmi, yang dalam istilah hukum Islam disebut wali muhakkam. Wali muhakkam ialah seorang yang diangkat oleh kedua calon suami istri untuk bertindak sebagai wali dalam akad nikah mereka. Apabila suatu pernikahan yang seharusnya dilaksanakan dengan wali hakim, padahal di tempat itu tidak ada wali hakimnya, maka pernikahan dilangsungkan dengan wali muhakkam. Caranya ialah kedua calon suami istri mengangkat seseorang yang mempunyai pengertian tentang ilmu agama (hukum-hukum Islam) untuk menjadi wali dalam pernikahan mereka. ${ }^{9}$

Di kalangan masyarakat suku Banjar di Kalimantan Selatan, termasuk di Kota Banjarmasin masih sering terjadi pernikahan dengan menggunakan wali muhakkam. Para calon suami istri, kebanyakan yang sudah berstatus duda atau janda, atau dalam perkawinan poligami, yang berhalangan nikah secara resmi karena walinya enggan atau halangan lainnya, mereka memilih kawin dengan menggunakan wali muhakkam, walaupun di berbagai pelosok daerah ini sudah ada wali hakimnya, yaitu Kepala Kantor Urusan Agama (KUA) atau petugas yang ditunjuk.

\footnotetext{
Abdurrahman, Op. cit., hlm. 118.

Deprtemen Agama RI, Pedoman Pegawai Pencatat Nikah dan Pembantu Pegawai Pencatat Nikah, (Jakarta: Proyek Peningkatan Sarana Keagamaan Islam, Zakat dan Wakaf, 1996/1997), hlm. 30.
} 
Dari pengamatan penulis, praktik pernikahan bawah tangan dengan menggunakan wali muhakkam ini biasanya ditangani oleh seseorang yang dianggap alim (ulama), seperti pemuka atau guru agama, tuan guru, habib, pimpinan pondok pesantren, penghulu tidak resmi, mantan penghulu atau seseorang yang dianggap mengetahui hukumhukum Islam. Secara umum pria yang menikah dengan menggunakan wali muhakkam ini ada orang awam, namun ada pula kalangan pengusaha, atau pejabat yang berpoligami. Begitu pula perempuannya, ada dari kalangan orang biasa, ada janda, bahkan ada yang dikenal sebagai artis. Walauun demikian kelihatannya mereka kurang mengetahui hukum Islam, sehingga cenderung mencari jalan pintas dan mudah saja dalam melangsungkan pernikahan, tanpa memiikirkan implikasi hukum dan sosialnya di Kemudian hari.

Mengingat praktik perkawinan dengan wali muhakkam hanya dibolehkan apabila di suatu daerah tidak ada wali hakimnya, padahal di Kota Banjarmasin, wali hakim itu ada pada setiap KUA, dan KUA juga tersebar sampai di lima Kecamatan yang ada (Kecamatan Banjarmasin Utara, Banjarmasin Selatan, Banjarmasin Barat, Banjarmasin Timur dan Banjarmasin Tengah), maka pernikahan dengan wali wali muhakkam yang terjadi di masyarakat ini perlu diteliti lebih mendalam dan dikaji status hukum dan implikasinya lebih lanjut. Mengapa terjadi pernkahan dengan wali muhakkam dan apa alasan hukum yang digunakan oleh wali muhakkam tersebut sehingga berani menikahkan orang.

Begitu pula persepsi ulama tentang pernikahan dengan wali muhakkam tersebut perlu diteliti lebih jauh. Kemungkinan para ulama tidak satu kata dalam menyikapi pernikahan dengan wali muhakkam, sehingga praktik tersebut terus saja berlangsung hingga sekarang. Untuk mengetahui masalah ini lebih jauh penulis tertarik meneliti dan membahasnya dalam sebuah tulisan yang berjudul: Pernikahan Dengan Wali Muhakkam (Studi tentang Implikasi dan Persepsi Ulama di Kota Banjarmasin).

\section{Pengertian dan Dasar Hukum Wali dalam Pernikahan}

Istilah wali diambil dari bahasa Arab, dengan akar kata waliya - yaliyu - walyan yang artinya amat dekat kepada, mengikutinya, mengiringinya tanpa batas. Istilah ini juga ada dalam bentuk kata alwaalii - wulan - waalin yang artinya hakim, pemerintah, wali. ${ }^{10}$

Al-Syaikh Sayyid Sabiq menyatakan, wali ada dalam pengertian umum dan ada yang khusus. Yang khusus ialah berkenaan dengan manusia dan harta benda. Wali yang dimaksudkan di sini adalah wali terhadap manusia, yaitu perwalian dalam pernikahan. ${ }^{11}$

Setiap pernikahan harus memerlukan wali. Adanya wali merupakan salah satu rukun dan syarat untuk sahnya suatu pernikahan, di samping zaujun (suami), zaujatun (1stri), wali, dan syabidain (dua orang saksi). Di dalam buku Pedoman Pembantu Pegawai Pencatat Nikah dinyatakan "pernikahan harus dilangsungkan dengan wali". Apabila dilangsungkan tidak dengan wali, maka pernikahan tersebut tidak sah. ${ }^{12}$

Adanya wali yang menyetujui pernikahan dimaksudkan agar pernikahan itu benar-benar disetujui oleh berbagai pihak yang terkait, dilaksanakan secara terbuka dan diketahui masyarakat, sehingga dengan demikian terwujud sebuah ikatan yang kuat antara suami istri. Ikatan yang kuat seperti ini pada gilirannya akan lebih menjamin terwujudnya kebahagiaan, sebagai salah satu tujuan dari perkawinan itu sendiri. Di dalam pasal 2 Kompilasi Hukum Islam (KHI) dinyatakan, perkawinan (pernikahan) ialah ikatan yang kuat (mitsaaqan ghaliizhan) antara suami istri untuk membentuk keluarga yang sakinah, mawaddah wa rabmah dan bersifat ibadah untuk mencari keredhaan Allah swt. ${ }^{13}$

Ditetapkannya wali sebagai salah satu persyaratan perkawinan bukanlah mengada-ada dan ingin mempersulit pelaksanaan perkawinan, melainkan didasari oleh sejumlah nash yang shahih. Di dalam sejumlah hadits diterangkan mengenai persyaratan adanya wali dalam pernikahan, di antaranya hadis yang artinya: Dari Abi Musa

10 Mahmud Yunus, Kamus Arab-Indonesia, Jakarta: Yayasan Penyelenggara Penterjemah dan Pentafsir Alquran, 1973), hlm. 5-6.

11 Sayyid Sabiq, Figh al-Sunnah, Jilid II, (Beirut: Dar alFikr, 1403 H), hlm. 111.

12 Departemen Agama RI, Pedoman Pembantu Pegawai Pencatat Nikah, (Jakarta: Badan Pembantu Kesejahteraan Masjid, 1991-1992), hlm. 29.

13 Abdurrahman, Kompilasi Hukum Islam di Indonesia, (Jakarta: Akademika Pressindo, 1992), hlm. 114. 
babwasanya Nabi saw berabda: Tidak ada nikah kecuali dengan adanya wali (HR Abi Daud). ${ }^{14}$

Hadits di atas menunjukkan bahwa pernikahan tanpa wali tidak sah. Hadits berikutnya juga menekankan yang artinya: Berkata Aisyab: Bersabda Rasulullah saw: siapa pun di antara wanita menikah tanpa seizin walinya maka nikahnya batal, nikahnya batal ,nikahnya batal. Jikea lelakinya telah menyenggamainya, maka ia berbak atas maharnya, karena ia telah menghalalkan kehormatannya. Jika pihak wali enggan menikabkannya, maka bakim bertindak menikabkan wanita yang tidak ada walinya (HR. Abi Daud). ${ }^{15}$

Dari hadits ini jelas bahwa pernikahan tanpa wali batal atau tidak sah secara hukum Islam. Ketidakabsahan ini bukan berarti wali bebas berkehendak menolak perwalian anak ketika anaknya mau menikah dan sudah ada pasangan yang cocok. Sebab jika wali enggan menikahkannya, maka yang berhak menjadi walinya adalah hakim. Dalam hal menikahkan perempuan harus disertai atau seizin wali tersebut. Para sahaba nabi memberlakukannya dengan tegas dan menghukum apabila ada orang yang melanggarnya. Di dalam kitab Nailul Authar diterangkan, yang Indonesianya sebagai berikut:"Bersumber dari Ikrimah bin Khalid, dia berkata: Pernah terjadi sebuah jalan penuh dengan kendaraan. Lalu ada seorang wanita janda di antara mereka yang menyerahkan urusannya ke tangan seorang lelaki yang bukan walinya, lantas laki-laki itu tadi menikahkannya. Ketika hal itu didengar oleh Umar, maka Umar menjatuhkan hukuman dera (jilid) kepada orang yang menikah dan yang menikahkannya, sekaligus membatalkan pernikahannya. Bersumber dari Asy Sya'bi, dia berkata: Tidak ada seorang pun dari sahabatsahabat Nabi saw yang paling keras tindakannya terhadap masalah dan pernikahan tanpa seorang wali melebihi Ali. Dia tidak segan-segan akan memukul pelakunya mengenai masalah ini" ${ }^{16}$

Keharusan adanya wali dalam perkawinan dan mengingat wali yang bertanggung jawab terhadap

14 al-Imam Abi Daud Sulaiman ibn al-Asy'ats al-Sijistani, Sunan Abi Daud, Jilid 2, (Surabaya: Maktabah Dahlan, tth), hlm. 229.

15 Ibid.

16 al-Imam Muhammad al-Syaukani, Nailul Authar, Juz 6, (Semarang: Asy-Syifa, 1994), hlm. 473. orang yang akan menikah atau dinikahkan, karenanya ia berhak menyatakan persetujuan, perizinan atau penolakannya, jika dipandangnya pernikahan itu membawa kebaikan atau keburukan.

Berkenaan dengan hal ini Asy Syaikh Sayyid Sabiq mengatakan bahwa karena perempuan banyak dipengaruhi oleh perasaannya, maka ia kurang rasional dalam memilih suami atau pasangan hidupnya. Oleh karena itu walinya berhak untuk mengurus akadnya, agar perkawinan dapat mencapai tujuan yang diinginkan. ${ }^{17}$

Kemudian Imam Asy Sayukani dalam Nailul Authar mengatakan: Menurut Abu Yusuf dan Muhammad, seorang wali berhak akan khiyar apabila tidak ada unsur kufu (keselarasan) antara kedua belah pihak yang melakukan pernikahan. Namun sebaliknya si wali wajib meluluskannya, apabila unsure kufu tersebut sudah dipenuhi. ${ }^{18}$

Dari keterangan di atas, seorang wali berhak untuk melakukan khiyar (membatalkan) pernikahan, apabila pasangan yang seharusnya ia bertindak wali itu, tidak kufu, hingga ia tidak yakin pasangan itu akan berbahagia. Tapi jika pasangan itu sudah kufu, maka wali wajib meluluskan atau mengizinkannya, tanpa harus menghalanghalanginya untuk menikah.

Dalam hal menikah dengan wali ini umumnya para ulama menyepakatinya, namun ada juga yang berbeda pendapat tentang hal ini. Tirmizi berkata: Hadits Nabi Saw, tidak sah nikah tanpa wali diikuti pula oleh segolongan ahli ilmu di kalangan para sahabat, di antaranya Umar, Ali, Abdullah bin Abbas, Abu Hurairah, Ibnu Umar, Ibnu Mas'ud dan Aisyah. Dan dari kalangan ahli fikih tabi'in di antaranya Said bin Musayyab, Hasan al Bisri, Syuraih, Ibrahim bin Nakhai, Umar bin Abdul Aziz dan lain-lain. Pendapat ini juga dikemukakan oleh Sofyan Tsauri, Auzai, Abdullah bin Mubarrak, Syafi'i, Ibnu Syahrumah, Ahmad, Ishak, Ibnu Hazm, Ibnu Abi Laila, Tabari dan Ibnu Tsaur. ${ }^{19}$

Kemudian Ibnu Rusyd dalam Bidayatul Mujtabid menerangkan pula: Ulama berselisih pendapat, apakah wali menjadi syarat sahnya nikah atau tidak.Berdasarkan riwayat Ashab, Imam Malik berpendapat bahwa tidak ada nikah tanpa wali, dan

\footnotetext{
17 Sayyid Sabiq, Op. cit., hlm. 113.

18 l-Syaukani, Op. cit., hlm. 474.

19 Sayyid Sabiq, Op. cit., hlm. 15.
} 
wali menjadi syarat sahnya nikah. Pendapat ini juga dikemukakan oleh Imam Syafi'i. Imam Abu Hanifah, Zufar, Asy Sya'bi dan Az Zuhri berpendapat bahwa apabila seorang perempuan melakukan akad nikah tanpa wali, sedangkan calon suami sebanding (kufu) maka nikahnya itu boleh. Daud memisahkan antara gadis dan janda. Dia mensyaratkan adanya wali pada gadis dan tidak mensyaratkan pada janda. ${ }^{20}$

Dari beberapa keterangan di atas, jelaslah bahwa dalam suatu pernikahan memang harus disertai atau atas seizin wali dan inilah pendapat kebanyakan ulama, baik orang yang dikawinkan itu gadis maupun janda. Dalam hal menikahkan janda, walaupun Imam Abu Daud, Hanafi dan Abu Yusuf membolehkan mengurus sendiri pernikahannya tanpa persetujuan wali, namun Nabi Saw sendiri tidak melakukan yang demikian.

Thabari berkata: Tentang riwayat Hafsah, ketika ia dalam status janda, diakadkan oleh Umar, dan bukan yang berkepentingan mengakadkan dirinya sendiri. Peristiwa ini membatalkan pendapat yang mengatakan bahwa wanita yang sudah dewasa dan mampu mengurus dirinya sendiri dapat mengawinkan dan mengakadkan diri sendiri tanpa wali. Andaikan demikian, tentu Rasulullah Saw meminang Hafsah secara pribadi (langsung) saja karena ia lebih berhak atas dirinya daripada ayahnya, dan beliau tidak usah melamar lewat orang lain yang tak berhak mengurus persoalannya serta mengakadkan nikahnya. ${ }^{21}$

Jadi meskipun para ulama bersilang pendapat tentang wali, namun berdasarkan hadits-hadits Rasulullah di atas, praktik Nabi dalam melamar istrinya serta pendapat umumnya sahabat dan ulama, maka wali merupakan syarat dalam perkawinan. Namun syarat tersebut bukan untuk menyulitkan, melainkan untuk menunjukkan tanggung jawab wali guna kebaikan rumah tangga yang dibina atas dasar kufu. Bila pasangan suami isteri sudah kufu, maka wali tidak boleh menghalangi atau tidak mengizinkan pernikahan. Jadi syarat keberadaan wali dalam pernikahan utuk memperkuat bahwa pernikahan itu atas setahu dan sepegetahuan walinya. Namun wali tidak berhak

20 Ibn Rusyd, Bidayatul Mujtahid, Jilid II, Alih bahasa Abdurrahman, et al., (Semarang: Asy-Syifa, 1990), hlm. 365.

21 Sayyid Sabiq, Loc cit. terlalu jauh dalam mengatur pernikahan wanita yang di bawah perwaliannya. Artinya jika si wanita sudah punya pasangan yang cocok, walaupun wali kurang berkenan, ia harus menyetujui, sebab sudah sesuai dengan kehendak wanita tersebut. Tentunya dengan tidak mengabaikan pertimbanganpertimbangan agama dalam perjodohan.

\section{Wali Hakim dan Persyaratannya}

Dimaksud dengan wali hakim ialah orang yang diangkat oleh pemerintah atau oleh lembaga masyarakat yang biasa disebut dengan nama abl alhalli wa al-aqdi untuk menjadi qadhi dan diberi wewenang untuk bertindak sebagai wali dalam suatu pernikahan.22

Wali hakim dapat dilakukan apabila calon pengantin perempuan berhalangan untuk menghadirkan wali nasab, atau wali nasabnya tidak ada. Tepatnya jika pengantin perempuan tersebut dalam kondisi: (a) Tidak mempunyai wali nasab sama sekali; atau (b) Walinya mafqud artinya tidak tentu rimbanya; atau (c) Wali sendiri yang akan menjadi pengantin laki-laki, sedang wali yang sederajat dengan dia tidak ada; atau (d) Wali berada di tempat yang jaraknya sejauh masafatul qasri (sejauh perjalanan yang membolehkan sembahyang qasar), yaitu 92,5 km; atau (e) Wali berada dalam penjara/tahanan yang tidak boleh dijumpai; atau (f) Wali adhal, artinya wali tidak bersedia/menolak untuk menikahkan; atau (f) Walinya sedang melakukan ibadah haji atau umrah. ${ }^{23}$

Dapat ditambahkan, wali hakim juga berwenang menikahkan apabila perempuan yang akan menikah tersebut walinya nasabnya tidak berhak menjadi wali, misalnya berbeda agama. Orangtua nonmuslim tidak berhak menjadi wali anak perempuannya yang muslim. Atau saudara lakilakinya yang nonmuslim tidak berhak menjadi wali saudara perempuannya yang muslim. Oleh karena itu wewenang menjadi wali beralih ke tangan hakim.

Dalam keadaan seperti di atas, wali hakim boleh dilakukan, kecuali jika wali nasabnya mawakilkan kepada orang lain untuk menjadi wali, maka orang lain itulah sebagai walinya, bukan wali hakim. Kemudian mengenai jarak yang mencapai masafatul qasri, untuk zaman modern sekarang di mana

Ibid., hlm. 52.
Ibid. 
transportasi dan komunikasi cukup lancar, jika ada wali nasabnya tetap perlu diberitahukan lebih dahulu jika menikah dengan wali hakim.

Keberadaan wali hakim ini memiliki sejarah tersendiri. Setelah agama Islam berkembang di Mekkah, orang-orang Quraisy merasakan perkembangan Islam merupakan ancaman terhadap kekuasaan mereka di Mekkah, karenanya merka mulai melancarkan berbagai gangguan dan penghinaan kepada Nabi Muhammad Saw dan memperhebat sikasaan di luar perikemanusiaan terhadap umat Islam. Nabi tidak tahan melihat penderitaan itu dan menyuruh mereka berhijrah ke Habsyah, berangkatlah rombongan pertama yang terdiri dari sepuluh orang pria dan empat orang wanita, di antaranya Usman bin Affan dengan istrinya Rukayyah (puteri Nabi), Zubair bin Awwawm, Abdurrahman bin Auf, Ja'far bin Abu Thalib, peristiwa ini terjadi pada tahun kelima kenabian. ${ }^{24}$.

Kemudian diiringi lagi oleh rombongan kedua yang terdiri dari delapan puluh tiga pria dan tujuh belas orang wanita. ${ }^{25}$ Dalam rombongan kedua ini ikut Ubaidillah bin Jahasy dengan istrinya Ramlah binti Abi Sofyan. Setelah berada beberapa bulan di Habsyah, Ubadillah bin Jahasy merubah agamanya menjadi pemeluk agama Nasrani namu tidak berapa lama ia meninggal. Ramlah tinggal di Habsyah tanpa ada yang membiayai hidupnya, nama Negus (raja) Habsyah yang sudah memeluk agama Islam mengirim surat kepada Rasulullah agar bersedia mengawini Ramlah dengan maharnya sebesar 4000 dinar dan Rasulullah menerimanya. Maka yang bertindak sebagai wali nikah Ramlah adalah Negus Habsyah karena Ramlah tidak mempunyai wali nasab di Habsyah. Dan baru pada tahun ketujuh hijriyah Surahbil bin Hasanah membawa Ramlah ke Madinah dan merubah namanya menjadi Ummu Habibah. ${ }^{26}$

Abu Daud dalam Sunannya mengabadikan peristiwa ini dalam tiga buah riwayat yang diterimanya dari Ummu Habibah pada jilid III,

24 Departemen Agama RI, Al-Qur'an dan Terjemahnya, (Jakarta: Proyek Pengadaan Kitab Suci Alquran, 1984/1985), hlm. 66.

25 Muhammad Husain Haekal, Hayatu Muhammad, Alih bahasa Ali Audah, (Jakarta: Lintera Antarnusa, 1990), hlm. 145.

26 Hasan Ibrahim Hasan, Tarikhu al-Islam al-Siyasi, (Kairo: Maktabah Nahdhah, 1964), hlm. 90. halaman 229, 235, dan 637. inilah wali hakim yang pertama yang terjadi dalam Islam yang terjadi di Habsyah, dan peristiwa ini terjadi dalam perkawinan Rasulullah Saw sendiri dengan seorang istrinya yang bernama Ummu Habibah yang pada waktu itu menjadi salah seorang yang berhijrah ke Habsyah untuk menyelamatkan agamanya.

Para ulama berbeda pendapat tentang kedudukan wali dalam perjanjian perkawinan. Menurut mazhab Hanafi perizinan wali bukan merupakan persyaratan sah nikah tetapi hanya penyempurna perjanjian perkawinan. Terutama bagi seorang janda ia berhak menentukan pilihannya. Alasannya adalah hadits berikut yang artinya: Dari Abu Hurairah ra Raulullah saw bersabda: seorang wanita janda tidak boleh dikawinkan tampa mendapatkan persetujuannya lebib dabulu. Seorang gads perawan tidak boleh dinikabkan kecuali atas seizinnya. Orang bertanya: bagaimana iæin wanita gadis itu? Rasul menjawab: kalau ia diam saja (HR al-Bukhari). ${ }^{27}$

Menurut mazhab Hanafi hadits di atas menerangkan sah pernikahan baik janda maupun perawan tanpa disyaratkan adanya perizinan wali karena itu izin wali bukan termasuk syarat sah nikah. Bahkan hadits ini menunjukkan persetujuan wanita yang punya diri lebih menentukan. Mazhab Hanafi juga mempergunakan qiyas untuk memperkuat pandangan mereka bahwa izin wali tidak menjadi syarat ialah mereka kiaskan perjanjian perkawinan dengan perjanjian lainnya seperti dalam perjanjian jual beli. Dalam perjanjian jual beli dianggap sah jual beli seorang perempuan sekalipun tidak mendapat izin dari walinya maka demikian juga berlaku dalam perjanjian perkawinan. ${ }^{28}$

Qiyas yang digunakan oleh kalangan Hanafi ini oleh sebagian ulama ditolak. Mempersamakan perjanjan perkawinan dengan jual beli tentu sulit diterima karena terkesan terlalu menyederhanakan masalah. Perkawinan merupakan sebuah ibadah sunnah dan ikatan yang sangat kuat (mitsaaqan gholiidhan), sedangkan jual beli hanyalah muamalah biasa.

27 al-Imam Abi Abdillah Muhammad bin Ismail bin Ibrahim al-Bukhari, Shabih al-Bukhari, Jilid III, Juz 6, (Beirut; Dar al-Fikr, $1401 \mathrm{H}$ ), hlm. 135.

28 al-Imam Muhammad Ismail al-Kahlani al-Shan'ani, Subulu al-Salam, III, (Beirut: Dar al-Fikr, tth), hlm. 117. 
Mazhab Syafi'i, Maliki dan Hanbali yang menganggap perizinan wali merupakan syarat sah perjanjian perkawinan, perkawinan tanpa izin wali tidak sah. Pendapat ini beralasan dari Al-Qur'an dan Sunnah.

Dari ayat Al-Qur'an ialah dari firman Allah Swt dalam surah al-Baqarah ayat 232 yang artinya: "Apabila kamu mentalak istri-istrimu, lalu habis iddabnya, maka janganlah kamu (para wali) menghalangi mereka kawin lagi dengan bakal suaminya apabila terdapat kerelaan di antara mereka dengan cara yang ma'ruf....".

Imam Bukhari meriwayatkan tentang sebab turunnya ayat di atas ialah karena ulahnya Ma'qal bin Yasar yang mengawinkan saudarinya dengan seorang lelaki Kemudian diceraikan oleh suaminya. Sesudah masa iddahnya habis datang bekas suaminya. Turunlah ayat di atas menegur tindakan Ma'qal yang kedudukannya sebagai wali, akhirnya Ma'qal membayar kafarah sumpahnya.

Dari ayat di atas dapat dipahami kalau perizinan wali tidak diperlukan tentunya Allah tidak menegur tindakan Ma'qal yang menyanggah perkawinan saudarinya yang tentunya ayat ini sudah memberikan pengertian bahwa perizinan wali itu menjadi syarat dalam sahnya perjanjian perkawinan. ${ }^{29}$ Karena itulah Imam Syafi'i sendiri pernah berkata: "Ayat itu) adalah sekuat-kuat dalil yang menetapkan bahwa perizinan wali (syarat sah nikah) karena kalau tidak demikian maka tidak ada artinya Allah melarang menghalangi dalam ayat". ${ }^{30}$ (Subuhu al Salam III : 120).

Kemudian dalil dari sunnah di antaranya gaduts bahwa "Tidak (sah) nikah kecuali dengan wali". (HR. Abu Daud). ${ }^{31}$ Hadits ini atau hadits lain yang senada menjelaskan bahwa Rasulullah saw menolak keabsahan nikah tanpa perizinan wali. Oleh karena itu perizinan wali menjadi syarat sahnya nikah. Sahnya perkawinan seorang perempuan bergantung kepada perizinan wali. Tanpa izin wali berarti nikahnya batal sebagaimaan disebutkan hadits terdahulu. Dengan demikian jelas perizinan wali itu menjadi syarat dalam perjanjian perkawinan.

Kelihatannya ada dua pendapat yang bertolak belakang. Menurut mazhab Hanafi perizinan wali

29 Ibid., hlm. 120.

30 Ibid.

31 al-Imam Abi Daud Sulaiman, Loc cit. tidak menjadi syarat sah nikah, sementara menurut mazhab Syafi'i, Maliki dan Hanbali perizinan wali menjadi syarat sah nikah dengan alasan yang sangat kuat. Karena itu Ibnu Munzir berkata: "Sesungguhnya tidak diketahui adanya salah seorang sahabat yang menyalahinya, karena ditunjuk oleh dalil-dalil hadits". ${ }^{32}$

Di dalam beberapa buah hadits dijelaskan tentang wali hakim yang dapat menggantikan kedudukan wali nasab di kala wali nasab tidak ada atau ada wali nasab namun enggan mengawinkan perempuan yang ada di bawah perwaliannya untuk menikah sedang perjodohan antara kedua calon suami istri seimbang. Rasulullah Saw bersabda: Artinya: "Maka apabila (wali nasab) enggan Sulthanlab yang menjadi wali bagi yang tidak mempunyai wali." (HR Abu Daud). ${ }^{33}$

Dimaksud dengan kata "Sulthan" dalam haditshadits di atas adalah pejabat tertinggi dalam Negara seperti contoh terdahulu Negus selaku kepala Negara Habsyah. Karena itulah penulis Kitab Subulu al Salam berkata: "Yang dimaksud dengan Sulthan ialah mereka yang mempunyai kekuasaan, baik ia zalim maupun adil, karena hadits-badits yang memerintabkan mentaati Sulthan bersifat umum yang mencakup Sulthan yang adil maupun zalim".34

Penulis Tanatu al Thalibin berkata: "Imam Akbar (kepala Negara) tidak menegahnya menjadi wali karena kefasikannya, sesuai dengan pendapat yang shahih". ${ }^{5}$ Kemudian Ahmad Husairi mengatakan: "Yang dimaksud dengan Sulthan di sini adalah Imam Akbar (Kepala Negara) atau Hakim atau siapa saja yang dilimpabkan wewenang oleb keduanya menjadi wali di kala tidak ada wali khusus (wali nasab)...Sulthan adalah wali bagi yang tidak ada walinya. Diriwayatkan babwa Negus mengawinkan Ummu Habibah dengan Rasulullah Saw, ketika (Ummu Habibah) berada di Habsyah". ${ }^{6}$

Jadi berdasarkan uraian di atas dapat disimpulkan orang yang ditunjuk oleh pemerintah adalah wali hakim bagi orang yang tidak mempunyai wali. Dengan demikian dapat dipahami

32 al-Shan'ani, Op. cit., hlm. 117.

33 al-Imam Abi Daud, Loc. cit.

34 Ibid., hlm. 118.

35 Said Bakri Muhammad Syatha al-Dimyathi, Khasyiyah I'anah al-Thalibin, Jilid III, (Beirut: Dar al-Fikr, tth), hlm. 305.

36 Ahmad Husairi, al-Nikahu wa al Qadhaya al Muta'aliqah bibi, (Kairo: Maktabah Kulliatil Azhar, 1968), h: 508. 
tidak sah orang yang menikah dengan tidak ada walinya, atau orang yang bukan orang yang ditunjuk oleh pemerintah tidak berhak menjadi wali hakim.

Dalam hadits yang dikemukakan di atas bahwa wali hakim dapat tampil sebagai wali nikah apabila wali nasab tidak ada atau wali nasab enggan (adhal) mengawinkan perempuan yang berada di bawah perwaliannya.

Karena itu penulis Kitab An Nikahu wa al Qadhaya al Muta'aliqah bibi berkata: "Adapun perwalian umum (Kepala Negara) ialah perwalian Sulthan di kala tidak didapat wali nasab namun dia enggan menikabkan perempuan (yang berada di bawah perwaliannya)". 37

Kemudian pada bagian lain dari kitab yang sama penulisnya berkata: "Sulthan banya saja mengawinkan wanita yang balighah di kala tidak ada wali atau walinya enggan atau walinya berada di tempat lain atau apabila walinya sendiri yang ingin mengawininya seperti anak paman wanita itu atau bekas tuannya atau qadhi." 38

Adapun kondisi seorang perempuan masih memiliki wali, tetapi walinya berada di tempat yang jauh, maka ukuran jauh di sini menurut Said Abdurrahman al-Alawi "Walinya berada pada jarak jaub yang membolebkan sembabyang qashar maka perwalian berpindab kepada hakim...". 39

Penulis Kitab An Nikabu wa al Qadhaya al Muta'aliqah bibi juga berkata: "Demikian juga bagi Sulthan mempunyai bak untuk mengawinkan di kala wali berada pada jarak jauh yang membolebkan sembahyang qashar atau apabila wali dalam ibramnya".40

Dari beberapa kutipan di atas dapat disimpulkan bahwa wali hakim itu ialah pejabat tinggi Negara (kepala negara) atau pejabat yang ditunjuk untuk tugas itu dari kepala Negara atau pejabat yang menerima pelimpahan tugas itu. Kondisi di mana wali hakim dapat bertindak sebagai wali selain karena wali nasabnya adhal, walinya tidak ada,juga karena wali berada di tempat yang jauh, yang jaraknya memungkinkan untuk shalat qashar. Untuk alasan terakhir ini tentu menjadi persoalan, sebab di tengah zaman

37 Ibid., hlm. 504.

38 Ibid., hlm. 503.

39 Said Abdurrahman al-Alawi, Bugyatu al Mustarsyidin, (Beirut: Dar al-Fikr, tth), hlm. : 203.

40 Ahmad Husairi, Loc. cit. mudahnya transportasi dan komunikasi sekarang ini, jarak yang relatif jauh tidaklah menyulitkan bagi wali untuk menjadi wali pernikahan wanita yang berada di bawah perwaliannya. Kecuali kalau jauh di sini benar-benar menyulitkan, maka barulah wali hakim dapat digunakan sebagai wali.

Persyaratan yang harus ada pada wali hakim tidak seperti syarat yang harus ada pada wali nasab. Seorang kepala negara yang zalim masih berhak menjadi wali bagi orang yang tidak mempunyai wali. Karena dari sekian banyak hadits mewajibkan taat kepada kepala negara sekalipun zalim dan fasik.

Bagi pernikahan yang menggunakan wali hakim, maka wali hakim ini menduduki urutan kedua yang berhak menjadi wali apabila wali nasab tidak ada. Menurut Sayyid Sabiq, Jumhur ulama seperti Malik, Tsauri, Laits dan Syafi'i berpendapat bahwa wali dalam pernikahan adalah wali waris, tetapi bukan paman dari ibu, bibi, dari ibu, saudara seibu dan keluarga zawil arham. Syafi'i berkata: Nikah seorang wanita tidak dapat dilakukan, kecuali dengan pernyataan wali qarib (dekat). Jika tidak ada, dengan wali yang jauh jika tidak ada, dengan wali hakim. ${ }^{41}$

Pernikahan dengan wali hakim dapat dilakukan apabila wali nasabnya gaib, di penjara atau enggan menjadi wali (adhal). Di dalam Peraturan Menteri Agama RI Nomor 2 Tahun 1987 Tentang Wali Hakim, pasal 2 ayat (1) dinyatakan: Bagi calon mempelai wanita yang akan menikah di wilayah Indonesia atau di luar negeri/wilayah ekstra territorial Indonesia ternyata tidak mempunyai wali nasab yang berhak, atau wali nasabnya tidak memenuhi syarat, atau mafqud atau berhalangan atau adhal, maka nikahnya dapat dilangsungkan dengan wali hakim. ${ }^{42}$

Para wali dalam hal ini tidak boleh merintangi perempuan yang diwali, sebab hal itu berarti ia berbuat zalim padanya. Jika wali menghalangi, maka perempuan itu berhak untuk mengadukannya ke pengadilan agar perkawinan dilangsungkan. Untuk itu wali tidak lagi

$41 \quad$ Ibid., , hlm. 22.

42 Departemen Agama RI, Pedoman Pegawai Pencatat Nikah dan Pembantu Pegawai Pencatat Nikah, Jakarta; Proyek Penigkatan sarana Keagamaan Islam, Zakat dn wakaf, 1996/1997), hlm. 271. 
dipindahkan dari seorang wali ke wali lainnya, melainkan langsung ditangani wali hakim.

Selanjutnya Sayyid Sabiq mengemukakan dilakukannya pernikahan dengan wali hakim ialah apabila ada pertentangan di antara wali-wali, dan bilamana walinya tidak ada dalam pengertian tidak ada yang absolut (mati atau hilang) atau karena ghaib. Bila datang laki-laki yang sepadan dan melamar dan melamar kepada perempuan yang sudah baligh dan ia menerimanya, tetapi tidak seorang pun dari walinya yang hadir waktu itu, misalnya karena ghaib sekalipun tempatnya dekat, tetapi di luar alamat pihak perempuan. Dalam keadaan seperti ini hakim berhak mengakadkannya, kecuali kalau perempuan dan laki-laki yang mau mengawininya itu bersedia menanti kedatangan walinya yang ghaib itu. Hal seperti menanti ini merupakan hak bagi perempuan, sekalipun waktunya masih lama. Jika laki-laki dan perempuan itu tidak mau menanti, tidak ada alas an untuk menyuruh mereka menanti. ${ }^{43}$ Jadi pernikahan dapat dilangsungkan dengan wali hakim apabila ada pertentangan sesama wali, walinya tidak ada atau gaib, baik karena mati atau hilang, maupun tidak ada di tempat (jauh).

Dari keterangan di atas, wali hakim mengambil alih peranan wali nasab, apabila wali nasabnya tidak ada: mati, hilang, tidak memenuhi syarat dan adhal (merintangi dan enggan menjadi wali), atau adanya pertentangan sesama wali. Adapun orang yang bertindak sebagai wali hakim, syaratnya adalah orang ditunjuk untuk tugas itu oleh pejabat yang berwenang, sebagaimana yang diatur dalam pasal 4 ayat (1) dan (2) Peraturan Menteri Agama Nomor 2 Tahun 1987:

1. Kepala Kantor Urusan Agama Kecamatan selaku Pegawai Pencatat Nikah ditunjuk wali hakim dalam wilayahnya untuk menikahkan mempelai wanita sebagai dimaksud pasal 2 ayat (1) peraturan ini.

2. Apabila di wilayah kecamatan, Kepala Kantor Urusan Agama Kecamatan berhalangan atau tidak ada, maka Kepala Seksi Urusan Agama Islam atas nama Kepala Kantor Departemen Agama Kabupaten/Kotamadya diberi kuasa untuk atas nama Menteri Agma menunjuk Wakil/Pembantu Pegawai Pencatat Nikah

43 Ibid., hlm. 30. untuk sementara menjadi wali hakim dalam wilayahnya.

Dengan adanya wali hakim yang demikian, maka selain ia memenuhi syarat dalam hal kedewasaan, keadilan, kemerdekaan dan mengerti hukum Islam, ia juga merupakan petugas resmi yang diangkat. Petugas tersebut adalah Kepala Kantor Urusan Agama (KUA), dan jika ia berhalangan maka sebagai gantinya orang yang ditunjuk oleh Kepala Seksi Urusan Agama Islam pada Kantor Departemen Agama Kabupaten/Kotamadya atas nama Menteri Agama. Jadi orang yang berwenang bertindak sebagai wali hakim bukan sembarang orang, melainkan orang yang ahli di bidangnya dan ditunjuk atau ditugaskan untuk melaksanakannya.

Pejabat yang berwenang ini, sekalipun telah ditunjuk dengan penetapan Pengadilan Agama, ia tetap minta kesediaan wali nasabnya sekiranya mau menjadi walinya. Hal ini dinyatakan dalam pasal 6 ayat (1) dan (2) Peraturan Menteri Agama.

(1) Sebelum akad nikah dilangsungkan, wali hakim meminta kembali kepada wali nasabnya untuk menikahkan calon mempelai wanita, sekalipun sudah ada penetapan Pengadilan Agama tentang adhalnya wali.

(2) Apabila wali nasabnya tetap adhal, maka akad nikah dilangsungkan dengan wali hakim. ${ }^{44}$

Dari uraian ini tergambar betapa selektifnya pelaksanaan nikah dengan wali hakim, dan ini menunjukkan bahwa wali nasab tetap diutamakan daripada wali hakim.

\section{Kedudukan Wali Muhakkam}

Kata mubakkam diambil dari bahasa Arab yang asal katanya hakama - yahkumu - bukman wabukumatan, yang artinya memegang perintah, mengepalai, menghukumkan, menjatuhkan hukum. 45 Mabkamatun artinya tempat berhakim. ${ }^{46}$ Menurut kaidah ilmu tashrif, kata hakama adalah timbangan (wazan) fa'ala yang diubah menjadi wazan fa'ala, sehingga kata bakama berubah menjadi hakama-yahkumu-tabkiman. Kata tabkim

44 Departemen Agama RI, Pedoman Pgawai Pencatat Nikah, (Jakarta:Proyek Peningkatan sarana Keagamaan Islam, Zakat dan Wakaf, 1996-1997),hlm. 35-6.

45 Muhammad Idris al-Marbawi, Kamus al-Marbawi, (Surabaya: Dar al-Ihya, th), hlm. 142.

46 Ibid., hlm. 143. 
dalam bahasa Indonesia yang berarti mengangkat hakim, menjadikan hakim. ${ }^{47}$

Dalam hal wali muhakkam dalam perkawinan diterangkan, yang dimaksud dengan wali muhakkam ialah seseorang yang diangkat oleh kedua calon suami isteri untuk bertindak sebagai wali dalam akad nikah mereka. Apabila suatu pernikahan yang seharusnya dilaksanakan dengan wali hakim, padahal tempat itu tidak ada wali hakimnya, maka pernikahan dilangsungkan dengan wali muhakkam. Caranya ialah kedua calon suami istri mengangkat seorang yang mempunyai pengertian tentang hukum-hukum untuk menjadi wali dalam pernikahan mereka. ${ }^{48}$

Dari keterangan di atas jelaslah bahwa jika pernikahan tidak dapat menghadirkan wali nasab, dan tidak pula dapat dilakukan dengan wali hakim, karena wali hakimnya tidak ada di mana pernikahan itu dilaksanakan, maka dalam keadaan demikian, pernikahan boleh dengan menggunakan wali muhakkam.

Sebagaimana disebutkan terdahulu, "wali muhakkam ialah seseorang yang diangkat oleh kedua calon suami istri untuk bertindak sebagai wali dalam akad nikah mereka". ${ }^{49}$ Keadaan yang membolehkan dilaksanakannya pernikahan dengan wali muhakkam diterangkan sebagai berikut:

Qurthubi berkata: Jika perempuan yang tinggal di tempat yang tak ada sultan dan tidak ada pula mempunyai wali, maka penyelesaiannya dapat, ia serahkan kepada tetangga yang dipercayainya untuk mengakadkannya. Dalam keadaan demikian tetangga tersebut telah menjadi wali. Karena setiap orang tentu perlu kawin, tetapi dalam melaksanakannya hendaklah sebaik-baiknya yang dapat dikerjakan.

Dalam hubungan ini Malik berkata tentang perempuan yang kondisinya lemah, ia boleh dikawinkan oleh orang yang diserahi urusannnya, karena ia tidak dapat pergi kepada sultan. Jadi seolah-olah sultan tidak berada di tempatnya, sehingga seluruh orang Islam secara umum dapat bertindak sebagai walinya.

Syafi'i berpendapat bahwa apabila dalam masyarakat terdapat perempuan yang tidak mempunyai wali, lalu ia mewalikannya kepada

47 Departemen P \& K RI, Op. cit., hlm. 884.

48 Dpartemen Agama, Op. cit., hlm. 53.

49 Ibid. seorang laki-laki untuk menikahkannya, maka hukumnya boleh. Karena hal itu merupakan tindakan yang mengangkat hakim. Dan orang yang diangkat sebagai hakim sama kedudukannya dengan hakim itu sendiri. ${ }^{50}$

Al-Imam Taqiyuddin al-Hushaini al-Dimasyqi mengatakan, Yunus bin Al Imam Al Husaini meriwayatkan dari Syafi'i bahwa jika dalam suatu masyarakat ada seorang wanita yang tidak memiliki wali sama sekali, lalu ia menguasakan atau mewakilkan perkaranya kepada seorang laki, termasuk dalam hal pernikahan, maka hukumnya boleh. Sebab hal itu termasuk pelimpahan kekuasaan dan status orang yang dilimpahi kekuasaan itu sama seperti hakim.

Imam al-Nawawi mengatakan, menurut alMawardi jika seorang wanita tidak punya wali sama sekali, maka ia memiliki tiga pilihan. Pertama, ia tidak menikah. Kedua, ia bisa menikahkan dirinya sendiri karena alas an darurat. Ketiga, ia bisa menguasakan/ menyerahkan urusanya kepada seseorang, kemudian orang itulah yang menikahkannya. ${ }^{51}$

Al-Syasyi mengatakan, bahwa dalam masalah seorang wanita tidak mempunyai wali sama sekali, ia boleh menguasakan kepada seorang ulama fikih yang ahli ijtihad. Pelimpahan kekuasaan seperti itu hukumnya sah, sehingga pernikahannya pun boleh. Tetapi dengan syarat pihak yang dilimpahi kekuasaan tersebut harus orang yang memang patut untuk memberikan keputusan, dan ini cukup sulit untuk ditemuka di zaman sekarang. Menurut pendapat yang kita pilih, pernikahannya sah apabila ia menyerahkan urusannya kepada orang yang adil (terjaga kehormatan dan dirinya), walaupun tidak sampai sebagai mujtahid. Itulah pendapat yang dikutip oleh Yunus bin Abdul A'la, seorang ulama yang jujur. ${ }^{52}$

Usman Abdullah al-Husaini dalam al-Qawanin al-Syar'iyyah menyatakan masalah nikah dengan wali muhakkam ini, yang kutipan aslinya berbahasa Arab Melayu, sebagai berikut: "Adapun jikalau tiada sekali-kali ada wali atau gaib dua marhalah

\footnotetext{
$50 \quad$ Sayyid Sabiq, Op. cit., hlm. 27.

51 Syaikh Muhammad Hafizh Ali al-Syuwaisyi, Tubfah alUrusy wa bi Hajah al-Nufus, Alih bahasa Abdul Rosyad Shiddiq, Kado Pernikahan, (Jakarta; Pustaka al-Kautsar, 2005), hlm. 51-2.

52 Ibid., hlm. 52.
} 
yaitu sembilan puluh pal atau dibawa tiada baulihi orang bertemu padanya atau wali itu 'adhal yakni enggan daripada menikahkan atau bersembunyi maka suatu daripada lima hal ini maka jikalau ada qadhi syar'I maka ialah yang menikahkan. Adapun jikalau tiada qadhi maka bertahkim daripadanya. Tetapi wajib diperiksa lebih dahulu akan walinya adanya sama tiadanya. Dan dekatnya sama jauhnya, hadirnya sama ghaibnya. Maka jikalau sudah sungguh-sungguh tiada walinya atau ghaibnya dua marhalah yaitu sembilan puluh pal dan tiada qadhi syar'i, maka itu waktulah bertahkim". 53

Jadi wali muhakkam dalam pernikahan dibolehkan bila seorang perempuan tidak memiliki wali sama sekali, walinya ghaib dalam jarak dua marhalah dan di daerah setempat tidak ada qadhi syar'i (hakim). Hal itu dilakukan setelah lebih dahulu diadakan penelitian secara seksama tentang keberadaan wali nasabnya.

Selanjutnya mengenai tata cara bertahkim, pengarang al-Qawanin al-Syar'iyyah ini mengatakan: Bermula syarat mubakkam yaitu orang yang menikabkan dibuat wali tabkim menikabkan maka adalah syaratnya itu bahwa ia adil. Tetapi sekiranya di dalam suatu tempat yang tiada bauulihi dapat adil maka yang sedikit fasiqnya. Dan wajib pula atas mubakkam itu babwa ia menyatakan maksudnya. Sebagai lagi tiada syaratnya babwasanya mubakkam itu mengetahui akan sekalian bukum syari maka hanya yag wajib atasya itulah mengetahui bukum yag yang ia lag memperkarakannya juwa. ${ }^{54}$

Dari keterangan ini diketahui bahwa wali hakim dalam pernikahan boleh dilakukan jika wali adhal, wali gaib dua marhalah. Jika dalam keadaan demikian wali hakim tidak ada maka boleh menikah dengan menggunakan wali muhakkam. Syarat wali muhakkam di sini ialah adil, atau yan sedikit fasiqnya, serta mengetahui hukum-hukum syara', khususnya yang berkaitan dengan perkara pernikahan yang sedang ia lakukan. Jadi tidak harus ia mengetahui semua hukum syara'.

Pernikahan dengan menggunakan wali mubakkam ini tidak mengikuti prosedur resmi dan

53 Usman bin Abdullah bin Aqil bin Yahya al-Alawi alHushaini, al-Qawanin al-Syariah Majalis al-Hukmiyyah wa al-Iftaiyyah, (Surabaya: Syirkah Maktabah wa alMathba'ah Salim Nabhan wa Auladuh, tth), hlm. 60-1.

54 Ibid., hlm. 61. tidak tercatat, sebagaimana diatur dalam undangundang. Di dalam Undang-Undang Nomor 1 tahun 1974 Tentang Perkawinan pasal 2 ayat (1) dan (2) dinyatakan: (a) Perkawinan adalah sah apabila dilakukan menurut hukum masing-masing agama dan kepercayaan. (b) Tiap-tiap perkawinan dicatat menurut peraturan perundang-undangan yang berlaku.

Kemudian di dalam Kompilasi Hukum Islam Pasal 5 juga dinyatakan: (a) Agar terjamin ketertiban perkawinan bagi masyarakat Islam perkawinan harus dicatat. (b) Pencatat perkawinan tersebut pada ayat (1), dilakukan oleh Pegawai Pencatat Nikah sebagaimana yang diatur dalam Undang-undang No. 22 Tahun 1946 jo Undangundang No. 32 Tahun 1954.

Perkawinan yang tidak tercatat, tidak bisa dipertanggungjawabkan, karena tidak mempunyai kekuatan hukum. Pada pasal 6 Kompilasi Hukum Islam ayat 2 dinyatakan: "Perkawinan yang dilakukan di luar pengawasan Pegawai Pencatat Nikah tidak mempunyai kekuatan hukum".

Menurut pernyataan di atas, maka perkawinan yang dilakukan dengan menggunakan wali mubakkam adalah perkawinan yang tidak tercatat secara resmi dan tidak bisa dipertanggungjawabkan menurut hukum. Oleh karena itu banyaklah konsekuensi atau implikasi yang akan timbul. Sebab banyak prosedur berurusan yang untuk melakukannya dipersyaratkan adanya buku nikah, sedangkan buku nikah hanya bisa dikeluarkan apabila pernikahan dilaksanakan secara resmi oleh KUA dan melalui prosedur yang sesuai dengan peraturan perundang-undangan yang berlaku.

\section{Praktik Pernikahan dengan Wali Muhakkam}

Di Banjarmasin ada sejumlah ulama, guru agama atau pemuka agama yang memerankan dirinya sebagai wali muhakkam. Ini merupakan suatu fenomena yang sudah lama terjadi di tengah masyarakat Islam di Kalimantan Selatan, termasuk di Kota Banjarmasin. Ulama dan guru agama dijadikan oleh masyarakat sebagai rujukan untuk menyelesaikan permasalahan yang mereka temui dan hadapi, termasuk yang berkaitan dengan perkawinan.

Kesediaan ulama dan pemuka agama menikahkan orang-orang dengan wali muhakkam, dengan menempatkan dirinya sebagai wali muhakkam pada kasus-kasus pernikahan di 
Banjarmasin, dapat dilihat sebagai suatu fenomena berikut:

Pertama, ulama yang berperan sebagai wali muhakkam tersebut telah mengenyampingkan aturan pernikahan dalam UUP, KHI atau aturan lain yang sejenis. Penyusunan UUP dan KHI sendiri sebenarnya sudah dilakukan oleh sejumlah ulama yang ahli di bidangnya, jadi tidak perlu diragukan kebenaran dan keabsahannya. Dalam proses sejarahnya, banyak ulama dilibatkan dalam penyusunan RUUP yang kemudian menjadi UUP. Begitu juga dalam penyusunan KHI, ulama peorangan dan kelembagaan seperti dari MUI juga dilibatkan.

Sikap ini dapat dianggap turut menjadikan perkawinan tersebut tidak memiliki kekuatan hukum yang kuat, sehingga mudah terjadi perpisahan dan tidak dapat digunakan untuk menuntut hak-hak suami istri dan anak-anak. Dapat pula dikatakan, pemuka agama yang berperan sebagai wali muhakkam tersebut sengaja atau tidak telah mengenyampingkan peraturan yang telah ditetapkan oleh pemerintah.

Segenap lapisan masyarakat, termasuk para ulama, guru agama dan pemuka agama, seyogyanya berperan mendukung aturan perkawinan yang digariskan oleh pemerintah di atas berkaitan dengan kewajiban pencatatan perkawinan, sebab aturan pemerintah dalam hal ini tidak bertentangan dengan agama. Dalam Islam, berlaku kewajiban taat terhadap pemerintah, suka atau tidak suka, sepanjang hal yang diatur dan disuruh oleh pemerintah tidak bersifat maksiat.

Di dalam Alquran surah an-Nisa ayat 59 dinyatakan: Artinya: Hai orang-orang yang beriman, taatilab Allah dan taatilah Rasul-Nya dan ulil amri di antara kamu. Kemudian jika kamu berlainan pendapat tentang sesuatu, maka kembalikanlah ia kepada Allah (Alquran) dan Rasul (sunnabnya), jika kamu benar-benar beriman kepada Allah dan hari kemudian. Yang demikian itu lebih utama bagimu dan lebih baik. akibatnya.

Ulil amr dalam ayat ini adalah para ualama, pejabat publik yang membuat suatu peraturan dan kebijakan, tempat masyarakat mengadukan permasalahannya, sesuai dengan bidang tugasnya. Dalam masalah perkawinan, pejabat publik yang mengurusnya ada pada instansi Pengadilan Agama dan KUA. Maka aturan-aturan yang dibuat oleh kedua instansi ini sepanjang untuk kemaslahatan individu dan masyarakat, mestinya dilaksanakan oleh segenap pihak yang berdiam dalam wadakah NKRI.

Dalam sebuah hadits diterangkan yang artinya: Dari Abdillah ra dari Nabi saw beliau bersabda: Wajib mendengar dan taat atas pemerintah orang muslim itu suka atau tidak suka sepanjang yang diperintah itu tidak. maksiat. Jika diperintahkan berbuat maksiat, maka tidak perlu didengar dan ditaati (HR al-Bukhari). 55

Kedua, pemuka agama yang menjadi wali muhakkam itu kelihatannya berupaya mencari celah dalam Hukum Islam. Di sini mereka lebih dahulu berpendapat bahwa ketika wanita yang akan menikah tidak ada walinya, walinya jauh atau walinya enggan, boleh dinikahkan dengan wali muhakkam.

Sebenarnya hadits-hadits dalam bab II telah secara tegas menyatakan pentingnya wali dalam suatu pernikahan. Dalam hadits-hadistnya beliau menyatakan: tidak ada nikah kecuali dengan adanya wali. Tidak ada di sini berarti tidak sah. Hadits lainya menyatakan wanita-wanita yang menikah tanpa seizin walinya, maka nikahnya tidak sah. Ucapan tidak sah bahkan sampai diulang oleh Nabi sebanyak tiga kali. ${ }^{56}$

Rasulullah saw juga menekankan bahwa bagi wanita yang tidak ada walinya, maka sultanlah yang menjadi wali. ${ }^{57}$ Istilah sultan ini sudah disepakati bahwa mereka adalah pejabat pemerintah yang berwenang atau ditunjuk. Saking pentingnya kedudukan sultan sampai-sampai sultan yang fasiq pun tetap dipakai sebagai wali bagi wanita yang tidak punya wali atau walinya enggan.

Tidak ditemui adanya nash bahwa pemuka agama dapat menggantikan kedudukan sultan ketika sultan tidak ada atau berhalangan, termasuk dalam pernikahan ini. Oleh karena itu pada dasarnya pemuka agama tidak berhak menjadi hakim. Pemuka agama yang diteliti secara tersirat menyatakan, mereka memiliki dasar hadit bahwa mereka berhak menjadi wali hakim (muhakkam), namun mereka enggan menyebut hadits dan kitabnya. Bahkan sekadar pendapat ulama mazhab

55 al-Imam Abi Abdillah Muhammad bin Ismail bin Ibrahim al-Bukhari, Shahih al-Bukhari, Jilid IV, Juz 8, (Beirut: Dar al-Fikr, 1401 H), hlm. 107.

56 al-Imam Abi Daud Sulaiman ibn al-Asy'ats al-Sijistani, Sunan Abi Daud, Jilid II, (Surabaya: Maktabah Dahlan, tth), hlm. 229.

57 Ibid. 
yang agak terperinci pun mereka tidak menyebutkannya. Keengganan ini menjadi indikasi, dasar yang mereka gunakan sangat lemah dan hanya ikut-ikutan dengan pendapat terdahulu. Boleh jadi kadar ilmu pengetahuan agamanya juga tidak begitu mendalam.

Pada kenyataannya banyak ulama dan guru agama yang ilmu dan kedudukannya diakui masyarakat tidak berani menikahkan orang dengan wali muhakkam. Ada pasangan mau menikah dengan wali muhakkam, lalu mereka mendatangi seorang guru agama (Gu Qd) yang cukup ahli di bidang agama, pandai membaca kitab-kitab kuning berbahasa Arab dan keulamaannya diakui masyarakat, ternyata guru agama tersebut menolak, sehingga pasangan tersebut mendatangi Kf dan guru ini pun bersedia menikahkan, karena sudah terbiasa melakukan hal demikian . Ini menunjukkan ulama yang ilmu agamanya lebih dapat diandalkan ternyata tidak mau menjadi wali muhakkam. Sekiranya memang ada dasar hukum yang kuat tentu tidak perlu disimpan. Bahkan kalau perlu dalam dokumen pernikahan yang mereka buat, dicantumkan dasar-dasar hukum pernikahan dengan wali muhakkam tersebut, sehingga lebih meyakinkan.

Sebenarnya, pernikahan dengan wali muhakkam dibolehkan sebagian ulama dalam keadaan tidak ada wali hakim. Pada bab II disebutkan beberapa pendapat yang membolehkan hal tersebut. Tetapi para pemuka agama yang diteliti ternyata juga tidak merujuk kepada dasar-dasar tersebut.

Sebenarnya dalam peraturan pernikahan terdahulu, pernikahan dengan wali muhakkam masih diberi tempat di masyarakat. Di dalam buku Pedoman Pegawai Pencatat Nikah dan Pembantu Pegawai Pencatat Nikah tahun 1996/1997 diterangkan adanya tiga macam wali, yaitu wali nasab, wali hakim dan wali muhakkam. Mengenai wali muhakkam yang dimaksudkan di sini ialah seseorang yang diangkat oleh kedua calon suami isti untuk bertindak sebagai wali dalam akad nikah mereka. Apabila suatu pernikahan yang seharusnya dilaksanakan dengan wali hakim, padahal di tempat tu tidak ada wali hakimnya, maka pernikahan dilangsungkan dengan wali muhakkam. Caranya ialah kedua calon suami istri mengangkat seseorang yang mempunyai pengertian tentang hukum- hukum agama untuk menjadi wali dalam pernikahan mereka. 58

Jadi wali muhakkam pada dasarnya menempatkan diri sebagai wali hakim dalam keadaan wali hakim tidak ada. Penyebab wali hakim boleh menjadi wali meliputi: Tidak mempunyai wali nasab sama sekali; Walinya mafqud, artinya tidak tentu keberadaannya; Wali sendiri yang akan menjadi mempelai pria, sedangkan wali yang sederajat dengan dia tidak ada; Wali berada di tempat yang jaraknya sejauh masafatul qasri (sejauh perjalanan yang membolehkan shalat qasar yaitu $92,5 \mathrm{~km}$; Wali berada dalam penjara atau tahanan yang tidak boleh dijumpai; Wali adhal, artinya wali tidak bersedia atau menolak untuk menikahkan; Wali sedang melakukan ibadah umrah/haji.59

Melihat alasan para wali muhakkam menikahkan orang, yang terbanyak karena walinya jauh dan enggan, dan ada juga karena berbeda agama. Semua itu memang dapat dijadikan untuk melangsungkan pernikahan dengan wali hakim. Masalahnya wali muhakkam tersebut menjadikan dirinya sebagai hakim, padahal hakim yang sesungguhnya masih ada, yaitu KUA (PPN) yang ada di tiap-tiap kecamatan beserta para Pembantu PPN yang ada di tiap-tiap kelurahan. Tetapi dalam peraturan yang berlaku sekarang, peluang wali muhakkam dalam pernikahan sudah dihapuskan.

Ketiga, alasan pernikahan dengan wali muhakkam adalah karena darurat. Hampir semua pemuka agama yang menjadi wali muhakkam menyatakan mereka mau menikahkan orang karena kondisi darurat. Dalam aturan Hukum Islam memang kondisi darurat membolehkan hal-hal yang terlarang atau tidak boleh. Salah satu kaidah fikih berbunyi yang artinya: Kebutuhan yang sangat penting diperlakukan sama dengan darurat. Keadaan darurat membolehkan melakukan hal-hal yang terlarang. .0

Penggunaan alasan darurat dalam pernikahan dengan wali muhakkam ini masih perlu diperdalam lagi, sebab darurat dalam hukum Islam tidak

58 Departemen Agama RI, Pedoman Pegawai Pencatat nikah dan Pembantu Pegawai Pencatat Nikah, (Jakarta: Proyek Peningkatan Sarana Keagamaan Islam, Zakat dan Wakaf, 1996/1997, hlm. 36.

59 Ibid, hlm. 35.

60 Masyfuk Zuhdi, Masail Fiqhiyah, (Jakarta: Haji Masagung, 1996), hlm. 21-2. 
sembarangan digunakan sebagai alas an memperingan hukum atau mengenyampingkan suatu ketentuan hukum. Allah swt menyatakan dalam QS al-Baqarah ayat 173 yang artinya: Sesungguhnya Allah banya mengharamkan bagimu bangkai, darah, daging babi, dan binatang yang ketika disembelih disebut nama selain Allah. Tetapi barangsiapa dalam keadaan terpaksa memakannya, sedangkan ia tidak menginginkannya dan tidak pula melampaui batas, maka tidak ada dosa baginya. Sesunggubnya Allah Maha Pengampun lagi Maha Penyayang.

Ayat di atas merupakan gambaran mengenai masalah darurat (emergency). Ketika seseorang terpaksa sehingga memakan sesuatu yang diharamkan, maka ia dibolehkan untuk menutupi rasa lapar, sepanjang tidak melampaui batas. Ibn Kasir menerangkan ayat ini sebagai berikut:"Abbad bin Syarahil al-Anzi berkata: ketika daerah kami menderita kekurangan makanan, kami pergi ke Medinah. Lalu aku masuk ke sebuah kebun dan memetik setangkai kurma dan aku makan, dan sisanya aku masukkan ke dalam saku. Tiba-tiba pemilik kebun itu datang, langsung memukulku dan mengambil bajuku. Lalu kejadian ini aku laporkan kepada Nabi saw dan beliau berkata kepada pemilik kebun itu: Mengapa tidak anda beri makan ketika ia lapar, dan mengapa tidak anda beri tahu ketika ia tidak mengerti. Lalu Nabi saw menyuruh mengembalikan bajuku dan menyuruh orang itu memberiku satu atau setengah wasaq kurma".

Abdullah bin Amr ra mengatakan bahwa Rasulullah saw ditanya tentang buah yang tergantung di pohon, maka jawab Nabi: siapa yang makan daripadanya hanya karena lapar, tanpa tujuan menyimpannya, maka tidak ada dosa dan tuntutan baginya. Masruq berpendapat, siapa yang terpaksa kemudian bertahan tetap tidak makan dan tidak minum, Kemudian ia sakit dan mati, dapat masuk neraka. Ini berarti makan bangkai, sekalipun bagi orang yang terpaksa, hukumnya wajib, bukan mubah. ${ }^{61}$

Yusuf al-Qardhawi menerangkan masalah darurat sebagai berikut:'Para ulama ahli fikih menetapkan suatu rinsip kaidah fikih: al-dharuratu tuqaddaru biqadriba (keadaan darurat itu dikira-kira menurut ukurannya). Seseorag sekalipun ia boleh

61 Ibn Katsir, Tafsir Ibn Katsir, Jilid I, (Surabaya: Bina Ilmu, 1993), h 295-6. tunduk kepada keadaan darurat, karena keadaan darurat membolehkan yang terlarang, namun ia tidak boleh menyerah begitu saja kepada keadaan tersebut. Ia tidak boleh menjatuhkan dirinya begitu saja kepada keadaan darurat dengan kendali hawa nafsunya. Dia harus terikat pada yang halal dan berusaha mencarinya, sehingga tidak tersentuh pada yang haram atau mempermudah alasan darurat". ${ }^{62}$

Di antara pemuka agama yang menjadi wali muhakkam beranggapan, masalah pernikahan harus dipermudah, jangan dipersulit. Di sini perlu ditegaskan, agama Islam memang mengandung ajaran-ajaran kemudahan, tidak ingin mempersulit penganutnya, tetapi itu bukan berarti dimudahmudahkan. Sekiranya semuanya serba mudah tentu tidak perlu ada syarat dan rukun pada setiap peribadatan. Apalagi menyangkut perkawinan yang menurut Alquran adalah sebuatan ikatan yang sangat kuat. Penggunaan prinsip kemudahan ini tentu harus proporsional. Misalnya kalau tidak punya harta tidak usah berzakat dan berhaji. Kalau tidak bisa berdiri silakan shalat dengan duduk, berbaring. Kalau bepergian boleh shalat dengan qashar, kalau sakit boleh mengqadha puasa, ibu menyusui boleh membayar hutang puasanya dengan fidyah dan seterusnya. Jadi prinsip kemudahan lebih pada hal-hal demikian. Bukan pada masalah pernikahan, di mana wali sebagai salah satu rukun nikah diabaikan begitu saja.

Memang dalam persoalan nikah ada hadits berbunyi: Artinya: Sebaik-baik nikah adalah yang mudah (HR. Abi Daud). ${ }^{63}$

Menurut peneliti, hadits ini memang menekankan perlunya kemudahan dalam pernikahan, tetapi penekanannya lebih pada masalah kesederhanaan pernikahan. Misalnya dalam hal memilih jodoh, yang ditekankan adalah kebaikan agamanya, bukan hanya mempertimbang harta, kecantikan atau keturunan. Kemudian dalam soal mahar hendaknya yang murah-murah saja, terjangkau oleh calon suami dan tidak memberatkan. Itu sebabnya di zaman Rasulullah

62 Yusuf al-Qardhawi, Halal dan Haram dalam Islam, Alih bahasa Muammal Hamidy, (Surabaya: Bina Ilmu, 1990), hlm. 48.

63 al-Imam Abi Daud Sulaiman ibn al-Asy'ats al-Sijistani, Sunan Abi Daud, Jilid II, (Surabaya: Maktabah Dahlan, tth), hlm. 238. 
para pemuda yang tidak punya harta yang berharga mahal boleh menyerahkan cincin besi, baju besi atau beberapa karung gandum sebagai mahar, bahkan juga mengajarkan Alquran kepada calon istrinya. ${ }^{64}$ Ini semua sebagai indikator bahwa perkawinan dalam Islam itu mudah dan murah. Jadi kemudahan itu bukan dengan meniadakan syarat dan rukunnya. Apalagi dalam soal perwalian, Rasulullah telah tegas menyatakan tidak ada (tidak sah) nikah kecuali dengan adanya wali. Alas an darurat dengan sendirinya tidak sembarang digunakan.

Di dalam Hukum Positif juga ada ketentuan tentang masalah darurat, yang diistilahkan dengan overmacht. Di dalam pasal 48 Kitab Undang-Undang Hukum Pidana (KUHP) dinyatakan: Barangsiapa melakukan perbuatan karena pengaruh daya paksa, tidak dipidana.

Pakar hukum pidana R. Soesilo menerangkan, kata terpaksa (darurat) harus diartikan mencakup paksaan lahir dan batin, rohani maupun jasmani. Kekuasaan yang tidak dapat dihindarkan ialah suatu kekuasaan yang berlebih, kekuasaan yang tidak dapat dilawan, suatu overmacht.. Mengutip Mr JE Jonkers kondisi darurat dibedakan dalam tiga macam:

1. Darurat yang bersifat absolut, maksudnya orang tidak bisa berbuat lain, tidak dapat mengelak. Misalnya seseorang yang tenaganya kuat memegang orang yang lemah dan melemparkannya ke luar jendela, sehingga pecah kaanya dan merusak barang-barang milik orang. Atau seseorang dipaksa menulis tanda tangan palsu atau di bawah ancaman, atau dihipnotis untuk melakukan tindak pidana di luar kesadarannya. Orang yang dipaksa demikian tidak dihukum, tetapi yang memaksanya yang harus dihukum.

2. Darurat yang bersifat relatif, maksudnya kekuatan yang memaksa tidak mutlak, tetapi orang yang dipaksa diberi kebebasan memilih dua perbuatan yang sama-sama tidak boleh dilakukan. Misalnya seseorang ditodong dan disuruh membakar rumah, jika tidak mau

64 Uraian-uraian tentang macam-macam dan kesederhanaan mahar di masa Rasulullah saw dapat dilihat lebih jauh pada bab nikah pada Shahih Bukhari Jilid III Juz 6. Juga pada Bulugh al-Maram karangan Ibn Hajar al-Asqalani, pada bab shadaq. membakar akan ditembak. Jadi di sini meskipun orang yang dipaksa berbuat misalnya membakar rumah, namun ia tetap tidak bisa dihukum.

3. Yang berupa keadaan darurat, maksudnya seseorang terpaksa berbuat sesuatu kejahatan karena dipaksa oleh keadaan dirinya sendiri. Misalnya dua orang terapung di laut, berpegang pada satu alat penampung. Untuk menyelamatkan diri, kalau sampai orang yang satu terpaksa melepaskan yang lain hingga mati, maka perbuatan itu tidak bisa dihukum. Contoh lain polisi mendobrak pintu atau memecah kaca jendela karena mau menolong wanita yang mau diperkosa dalam rumah, juga tidak bisa dihukum, walaupun ia telah merusak barang milik orang. Atau seseorang mendapat panggilan untuk menjadi saksi di dua pengadilan sekaligus pada waktu dan jam yang sama, sehingga ia terpaksa menghadiri salah satunya saja. Keadaan seperti ini juga tidak dikenakan hukuman. ${ }^{65}$

Contoh-contoh di atas adalah kondisi darurat di mana seseorang boleh melakukan pelanggaran dan karenanya tidak dihukum. Melihat cara dan sikap pemuka agama yang menikahkan orang dengan wali muhakkam, tampak kondisi darurat belum terpenuhi. Pemuka agama tersebut belum terlihat mengusahakan menghubungi keluarga calon mempelai wanita yang berhak menjadi wali nasab, lalu membujuknya supaya berkenan merestui pernikahan. Seharusnya ia ikut berusaha secara optimal, memberikan pengarahan dan penyadaran supaya mau menjadi wali nikah. Usaha ini patut dilakukan, mengingat pemuka agama itu dibayar atas jasanya. Kalau dilakukan pendekatan tidak mustahil keluarga si wanita berkenan menjadi wali. Kalau terjadi pernikahan maksimal dilakukan di bawah tangan dengan tetap ada wali, sehingga pelanggaran hukumnya tidak seberapa, bahkan dapat dilakukan pernikahan secara resmi melalui KUA.

Pemuka agama tersebut juga tidak terlihat melakukan usaha membujuk pasangan yang menikah agar bersabar dahulu sambil menunggu restu wali, misalnya kalau walinya jauh atau berada di luar daerah. Wali yang berada di luar daerah sebenarnya dapat mewakilkan perwaliannya kepada

65 R. Soesilo, KUHP Serta Komentar-komentarnya, (Bogor; Politeia, 19990), hlm. 63. 
orang lain yang dapat dipercaya dan perwalian demikian dapat dibenarkan dalam hukum Islam. Ini dapat dilihat dari adanya calon suami istri yang sama-sama pejaka/perawan, sehingga tentu sangat mudah jika menikah melalui KUA. Masalahnya hanya karena wali nasab jauh di Jawa dan susah dihubungi serta alas an ekonomi. Wali yang jauh daat diwakilkan kepada orang lain, atau ada persetujuan tertulis untuk menikahkan anaknya. Sedangkan alasan ekonomi tidak begitu mendasar. Jika dianggap perlu KUA bersedia menikahkan orang secara cuma-cuma dengan perlengkapan surat keterangan tidak mampu dari Ketua RT atau Lurah setempat dan itu surat begini mudah saja diperoleh. Menikah dengan wali muhakkam tetap saja perlu biaya dan tidak mustahil lebih besar.

Sebenarnya tidak semua kasus perkawinan yang dilakukan dengan wali muhakkam itu benar-benar darurat sehingga harus dinikahkan dengan wali muhakkam. Ada wanita yang ayahnya berbeda agama, sehingga tidak berhak menjadi wali. Untuk keadaan seperti ini tidak ada susahnya untuk menikah dengan wali hakim di pengadilan agama atau di KUA.

Bahkan untuk calon istri yang tidak direstui walinya sekalipun, pernikahan dengan wali hakim tetap dipermudah. Para ulama sependapat wali tidak berhak merintangi perempuan yang diwalii karena kalau hal itu terjadi berarti berbuat zalim kepadanya. Kalau perempuan itu sudah punya calon suami yang cocok dan sanggup membayar mahal mitsil, wali tidak berhak menghalangi pernikahannya. Maka calon pengantin berhak mengadukan masalahnya kepada pengadilan dan pengadilan dapat melangsungkan perkawinan semacam itu. Dalam keadaan begini perwalian tidak perlu pindah dari wali yang zalim yang adhal kepada wali lain, tetapi dapat langsung kepada wali hakim. ${ }^{66}$

Kalau pengadilan yang mengambil alih perwalian dengan menjadi wali hakim, maka permasalahannya akan selesai, sebab pengadilan inilah lembaga berwenang yang dipercayai undangundang untuk melaksanakan perkawinan demikian. Kalau dilaksanakan pihak lain, seperti pemuka agama, maka hal itu masih mengundang keraguan, dan bisa mengakibatkan pihak keluarga melakukan

66 Sayyid Sabiq, Fikih Sunnah 7, Alih bahasa Moh.Thalib, (Bandung: Almaarif, 1987), hlm. 27.. tuntutan sehingga terjadi masalah. Sebab pemuka agama demikian tidak diberi kewenangan, baik oleh pemerintah maupun masyarakat.

Ketiga, alasan daripada pasangan berbuat zina, tidak selalu tepat. Perzinaan sebagai perbuatan terkutuk dan berdosa besar memang harus dihindari, tetapi cara menghindarinya tentu bukan dengan melakukan pelanggaran baru. Memang bisa saja dipakai kaidah fikih: idza ta'aradha dhararani fuddhila akhaffuhuma (jika ada dua bahaya/risiko, maka dahulukan bahaya yang lebih ringan). ${ }^{67}$ Maksudnya daripada pasangan berbuat zina sebagai suatu pelanggaran hukum lebih baik dilakukan pernikahan dengan wali muhakkam yang juga pelanggaran hukum. Tetapi menghilangkan suatu bahaya tidak boleh dengan melakukan bahaya lainnya. Kaidah fikih menyatakan: al-dhararu la yuzalu bi al-dharara (bahaya tidak boleh dihilangkan dengan bahaya lainnya). ${ }^{6}$

Menghindari zina tetapi dengan melakukan pernikahan yang kontroversial dan diragukan keabsahannya, bahkan banyak implikasinya yang merugikan, tentunya tidak sejalan dengan maksud hukum Islam bidang perkawinan yang bertujuan untuk mewujudkan kemaslahatan dan kebahagiaan suami istri dan keturunannya. Langkah begini dapat dilakukan dalam kondisi yang benar-benar darurat, sedangkan dalam kasus-kasus yang ada kelihatannya belum begitu darurat. Masih ada peluang usaha lain, namun peluang itu sengaja tidak dilakukan atau dihindari oleh pemuka agama yang menikahkan dan pasangan yang menikah. Sekiranya sudah diusahakan maksimal tetap gagal menikah, maka bolehlah dikatakan sudah darurat.

Memang di masa lalu, ketika hakim masih langka, misalnya orang tinggal di hutan, di laut atau tempat-tempat yang terisolasi yang tidak ada hakimnya, bisa saja wali muhakkam dibolehkan. Qurthubi mengatakan, jika perempuan tinggal di tempat yang tidak ada sultannya dan tidak pula mempunyai wali, maka penyelesaiannya dapat ia serahkan kepada orang yang dipecayaiya untuk mengakadkannya. Dalam keadaan demikian orang tersebut telah bertindak sebagai wali, karena setiap orang tentu perlu kawin tetapi dalam melaksanakan

\footnotetext{
67 Masyfuk Zuhdi, Op. cit., hlm. 137.

68 Ibid., hlm. 88.
} 
hendaknya dilakukan sebaik-baiknya yang dapat dikerjakan. ${ }^{69}$

Jelas kebolehan menikah dengan wali muhakkam hanya dalam keadaan tertentu yang tidak ada sultan dan tidak ada walinya. Dalam keadaan demikianlah para ulama terdahulu membolehkan. Sekarang, dengan sudah tersebarnya sultan (wali hakim) di mana-mana, maka kebolehan itu bisa saja tidak berlaku. Dalam hukum Islam, aturan hukum bisa saja berubah sejalan dengan perubahan zaman. Kaidah fikih menyatakan: taghayyur al-abkami bi tahayyuri alazminati wa al-amkinati wa al-abwali (hukum-hukum itu bisa berubah karena perubahan zaman, tepat dan keadaan). $7^{70}$

Selain itu karena pemerintah sebagai sultan atau hakim telah melarang menikah dengan wali muhakkam, mestinya tidak ada perbedaan pendapat lagi karena ketentuan penguasa itu berfungsi menghilangkan ikhtilaf. Ada kaidah fikih yang berbunyi: hukmu al-bakimi ilzamun wa yarfa'u alkhilaf (keputusan pemerintah itu mengikat untuk dilaksanakan dan menghilangkan perbedaaan pendapat). ${ }^{71}$

Oleh karena itu para pemuka agama harus berusaha untuk keluar dari melakukan hal-hal yang bersifat ikhtilaf supaya perbuatannya tidak menjadi kontroversial dan sorotan, karena sudah ada ketentuan hukum yang satu. Jadi bukannya mencari-cari alas an untuk melakukan ikhtilaf. Kaidah fikih menyatakan: al-khuruju min al-kbilafi mustababbun (menghindari perbedaan pendapat itu disunatkan. ${ }^{72}$

Dengan demikian dapat ditegaskan pernikahan dengan wali muhakkam yang telah dilakukan oleh sejumlah pemuka agama di Kota Banjarmasin yang notabane termasuk daerah perkotaan dan tersedia sejumlah wali hakim di setiap KUA Kecamatan sangat diragukan keabsahannya baik menurut hukum Islam apalagi menurut Hukum Positif. Dasar hukum dan alasan-alasan yang mereka pergunakan, baik dasar agama maupun pertimbangan keadaan darurat masih sangat lemah dan tidak dapat dipertanggungjawabkan.

69 Sayyid Sabiq, Loc. cit..

70 Masyfuk Zuhdi, Op. cit., hlm. 183.

71 Majelis Ulama Indonesia, Himpunan Fatwa MUI, (Jakarta: Departemen Agama RI, 2003), hlm. 173.

72 Masyfuk Zuhdi, Op. cit., hlm. 138.

\section{Keadaan dan Konsekuensi Pernikahan dengan} Wali Muhakkam

Dari enam pasangan suami istri yang menikah dengan wali muhakkam di Kota Banjarmasin yang penulis teliti, dapat dikategorikan sebagai berikut:

1. Dari segi daerah asal, kebanyakan memang pendatang dari luar daerah atau luar pulau. Mereka bekerja dan berdomisili di Banjarmasin dan bertemu jodohnya di Banjarmasin. Ada juga yang sengaja datang ke Banjarmasin untuk dapat dinikahkan dengan wali muhakkam, karena di daerah asalnya tidak ada yang mau menikahkan dengan cara demikian.

2. Dari segi status, kebanyakan berstatus duda, janda, namun ada juga yang perawan. Status duda atau janda berarti pernah bercerai sebelumnya. Untuk menikah lagi harus ada bukti berupa surat cerai, dan bukti demikianlah yang tidak mereka punyai, karena bercerai hanya di bawah tangan. Keadaan inilah yang ikut mendorong sehingga mereka memilih untuk menikah dengan wali muhakkam, karena merasa tidak memadai lagi menikah di KUA. Biasanya pasangan calon suami istri menikah di KUA untuk pernikahan pertama, sedangkan sesudahnya cenderung mencari jalan yang lebih mudah dan praktis. Tetapi kenyataannya ada juga pasangan yang berstatus perjaka dan perawan juga menikah dengan wali muhakkam. Hal ini tentu sangat disayangkan, karena sebenarnya mereka sangat memungkinkan untuk dinikahkan secara resmi melalui KUA. Ini menunjukkan menikah dengan wali muhakkam seolah sudah memiliki kekuatan hukum, padahal sebenarnya tidak demikian.

3. Dari segi alasan menikah dengan wali muhakkam, kebanyakan karena walinya adhal, tidak ada, jauh dan sulit dihubungi, dan juga karena berbeda agama, sehingga orang tuanya terhalang untuk menjadi wali.

4. Dari segi pendidikan, kebanyakan pasangan yang menikah berpendidikan relatif rendah. Hal ini dapat menyebabkan mereka agak buta hukum, sehingga tidak mengetahui secara detail tentang seluk-beluk hukum Islam di sekitar perkawinan. Namun di antara mereka ada juga yang bertitel sarjana. Ini juga menunjukkan tingginya pendidikan tidak 
berbanding lurus dengan pemahaman terhadap hukum Islam.

5. Dari segi risiko pernikahan dengan wali muhakkam, kebanyakan pasangan belum menyadari dampak negatifnya. Keabsahan pernikahan mereka tidak pernah diragukan oleh masyarakat setempat. Hanya bagi yang sudah punya anak merasa kesulitan untuk mendapatkan akta kelahiran karena tidak memiliki buku nikah.

Dari beberapa keadaan di atas dapat ditegaskan pernikahan dengan wali muhakkam cenderung dilakukan oleh orang luar Banjarmasin atau pendatang. Dengan kata lain wali muhakkam cenderung menikahkan orang luar, bukan warga Banjarmasin asli. Hal ini dapat dimaklumi karena kalau warga Banjarmasin asli, kemungkinan besar wali nasabnya masih ada, baik wali dekat maupun jauh. Jauhnya jarak antara wali muhakkam dengan wali nasab inilah yang memungkinkan praktik pernikahan dengan wali muhakkam kelihatannya tetap berjalan mulus dan aman-aman saja, tidak ada tuntutan hukum atau gugatan dari keluarganya. Misalnya wali nasab berada di Balikpapan, Samarinda, Jawa, dll, tentu sulit bagi mereka melakukan tuntutan atau gugatan.

Tetapi ada juga yang jaraknya relatif dekat, di mana wali nasab beralamat di Kandangan HSS. Jarak Kandangan - Banjarmasin memang sudah melewati batas masafatul qasri, tetapi sebenarnya persoalannya bukan pada jarak. Sekarang ini persoalan jarak tidak mendasar lagi sebab transportasi dan komunikasi sudah begitu lancar dan mudah. Masalahnya wali nasabnya adhal, sehingga pasangan yang mau menikah pergi ke tempat lain. Seharusnya wali muhakkam tidak menikahkan, sebab pemuka agama di daerah asal saja enggan menikahkan. Akan lebih baik dilakukan pendekatan lebih dahulu agar pernikahan resmi bisa dilakukan, minimal di bawah tangan dengan tetap wali nasab.

Banyaknya pasangan yang berstatus duda atau janda yang melakukan pernikahan dengan wali muhakkam di segi alasan-alasan praktis agar cepat dan mudah, di satu sisi dapat dipahami. Sebab bagi pasangan demikian yang penting mereka dapat berkumpul sebagai suami istri. Tetapi sebenarnya hal ini mengandung banyak risiko. Terlepas dari status hukumnya, pernikahan demikian terkesan sangat longgar. Tidak adanya buku nikah dapat membuat suami istri tersebut sangat mudah untuk bercerai nantinya. Terbukti satu dari pasangan yang menikah sudah bercerai, padahal pernikahanya baru dalam hitungan bulan. Walaupun ada pernikahan dengan wali muhakkam yang dibuatkan dokumen atau surat-menyuratnya, namun suratsurat itu tidak ada kekuatan hukumnya, kecuali sebatas catatan bahwa mereka pernah menikah. Ketiadaan buku nikah ini berakibat tidak terjaminnya hak-hak suami istri untuk diadukan ke pengadilan sekiranya terjadi masalah.

Dalam kehidupan rumah tangga hampir selalu terjadi masalah, besar atau kecil. Boleh dikatakan tidak ada rumah tangga yang sunyi dari permasalahan dan pertengkaran. Permasalahaan tersebut biasanya berkisar pada masalah ekonomi, poligami, perselingkuhan dan sebagainya. Mereka yang menikah dengan wali muhakkam kemungkinan lemah di segi ekonomi dan rentan bertengkar. KUA dan Pengadilan Agama dapat memfasilitasi bila pasangan ingin berkonsultasi. Tentunya pasangan yang difasilitasi adalah yang menikah secara resmi.

Pasangan yang menikah dengan wali muhakkam demikian, jika mengalami masalah cenderung langsung bercerai, tanpa perlu lagi ke pengadilan. Sebab dari awal mereka sudah tidak melibatkan pengadilan dan KUA dalam urusan pernikahannya. Ini berarti pernikahan dengan wali muhakkam cenderung mempermudah terjadinya perceraian, padahal perceraian merupakan perbuatan halal yang dibenci oleh Allah swt. Di kalangan responden baru sebentar menikah sudah satu yang bercerai, karena pernikahan yang begitu mudah berakibat perceraiannya juga mudah. Hal ini dilarang agama, sebagaimana dinyatakan dalam hadits yang artinya: Dari Ibn Umar dari Nabi saw beliau bersabda: Perbuatan halal yang dibenci di sisi Allab adalab thalaq (HR. Abi Daud). ${ }^{73}$

Alasan menikah dengan wali muhakkam umumnya karena wali adhal, jauh, sulit dihubungi dan berbeda agama. semua alasan ini menjadi dasar dibolehkannya pernikahan dengan wali hakim. Data yang terungkap menunjukkan pasangan tersebut tidak terlihat usahanya untuk menikah dengan wali hakim. Mereka membayangkan dan sudah mencap urusannya akan sulit tanpa ada

73 al-Imam Abi Daud Sulaiman al-Sijistani, Op. cit., hlm. 255. 
usaha nyata. Seharusnya mereka berusaha lebih dahulu menikah dengan wali hakim. Adanya alasan mendasar tentu wali hakim akan bersedia. Dengan tidak adanya usaha, maka keabsahan pernikahan mereka dengan wali muhakkam menjadi sangat lemah. Sekiranya mereka sudah berusaha maksimal, tetapi wali hakim tetap saja mempersulit, barangkali masih bisa diterima dan dianggap sah merka menikah dengan wali muhakkam. Kesalahan di sini tidak saja pada yang menikahkan (menjadi wali muhakkam), tetapi juga pada pasangan yang menikah.

Kebanyakan pasangan yang menikah dengan wali muhakkam berpendidikan rendah, walaupun ada satu pasangan responden yang sarjana. Keadaan ini membuat mereka buta hukum, baik hukum agama maupun hukum negara. Akibatnya langkah yang dilakukan adalah asal menikah, bukan menikah sesuai praturan agar kekuatan hukumnya terjamin. Rendahnya pendidikan, mengakibatkan mereka mudah dieksploitasi dan dibodohi, apalagi atas nama agama. Dengan sedikit penjelasan dari pemuka agama yang akan menjadi wali muhakkam, mereka akan menerimanya tanpa berpikir panjang lagi. Apalagi bagi etnis tertentu, kedekatan dengan ulama dan pemuka agama sangat kuat, sehingga mereka cenderung menaati saja walaupun dengan mengabaikan peraturan pemerintah.

Keadaan ini diperparah oleh sikap masyarakat yang tidak kritis. Pada kenyataannya bagi masyarakat yang penting suatu pasangan menikah, resmi atau tidak resmi, dengan wali nasab, wali hakim atau wali muhakkam, bagi mereka bukan persoalan lagi. Ini tampak dari peristiwa yang dialami salah seorang responden. Setelah melihat pergaulan keduanya intim, masyarakat mencari pemuka agama yang mau menikahkan, dan akhirnya ketemu pemuka agama yang bersedia menjadi wali muhakkam. Setelah dinikahkan, bagi masyarakat urusannya sudah selesai. Kalau tidak dinikahkan, mereka khawatir akan menanggung dosanya. Pandangan masyarakat yang tidak kritis ini, ditambah adanya pemuka agama yang bersedia menikahkan berakibat pernikahan dengan wali muhakkam selalu saja terjadi.

Adanya pasangan yang berpendidikan sarjana yang juga memilih menikah dengan wali muhakkam juga patut disesalkan. Sebagai orang berpendidikan mestinya mereka menjadi contoh bagi masyarakat, seharusnya mereka menikah sesuai prosedur dan sesuai peraturan, sebagai cerminan bahwa mereka mengerti hukum. Kalau menikah dengan wali muhakkam, maka hal itu bisa menjadi preseden buruk bagi orang awam untuk menikah dengan cara yang sama.

Kelihatannya pasangan yang menikah dengan wali muhakkam belum benar-benar merasakan dampak atau implikasi dari pernikahan demikian. Dari masyarakat tidak diprotes dan dari mereka sendiri baru merasakan persoalan dalam hal pengurusan akta kelahiran yang mensyaratkan adanya buku nikah. Keadaan ini tentu tidak bisa dijadikan justifikasi (pembenaran) untuk menikah dengan wali muhakkam. Tidak adanya protes dari masyarakat semata karena masyarakat kita memang buta hukum, dan karena kesibukannya mereka memang memilih untuk acuh tak acuh dari campur tangan terhadap urusanorang lain.

Sebenarnya implikasi dari pernikahan dengan wali muhakkam tidak semata terkait dengan akta kelahiran. Di situ juga ada masalah hak dan kewajiban suami istri yang jika menikah secara resmi akan dijamin oleh undang-undang. Orang yang menikah secara resmi, selain mendapatkan buku nikah, biasanya juga mengucapkan ikrar sighat taklik untuk melindungi hak-hak istri, baik berkaitan dengan kebutuhan jasmani maupun rohani. Juga diberikan nasihat-nasihat perkawinan dan buku-buku pedoman untuk membentuk keluarga bahagia dan sejahtera yang resmi dari pemerintah, yang tidak dijual di pasaran. Ketiadaan buku nikah berarti undang-undang tidak bisa melindunginya sekiranya terjadi permasalahan. Jadi risiko pernikahan terpaksa ditanggung sendiri oleh pasangan yang menikah tersebut.

Jadi tampak di sini bahwa pasagan yang menikah dengan wali muhakkam cenderung hanya berpikir jangka pendek, mencari jalan pintas dan mencari mudahnya saja. Mereka tidak memikirkan risiko hukum atas tindakannya, baik menurut Hukum Islam maupun Hukum Positif dan tidak pula memikirkan prospek kehidupan pernikahannya ke depan. Oleh karena itu sekiranya memungkinkan, pasangan demikian hendaknya memperbaharui pernikahannya secara resmi di KUA, supaya memperoleh legitimasi sebagaimana mestinya. 


\section{Pandangan Ulama terhadap Pernikahan dengan Wali Muhakkam}

Dari enam ulama yang peneliti pilih sebagai responden yaitu alm. Drs. KH Adenani Iskandar, Drs. H. Ibrahim Hasani, Drs.H. Humaidi Dahlan, Lc, Drs. H. Tabrani Basri, H. Junaidi As Khalid dan alm. Drs. H. Karsayudha, SH, MAg., ternyata hampir semuanya berpendapat pernikahan dengan wali muhakkam tidak sah. Hal ini karena menurut mereka hanya sultan yang berwenang bertindak sebagai wali hakim bagi wanita yang tidak memiliki wali, wali jauh, wali berbeda agama atau wali tidak merestuinya (adhal). Orang di luar sultan tidak memiliki hak melakukannya. Kondisi darurat sebagai celah hukum untuk menikah dengan wali muhakkam kurang terpenuhi, sebab belum ada usaha para pihak untuk menikah secara resmi.

Para ulama yang dijadikan responden ini, menurut peneliti cukup dikenal keulamaannya. Oleh karena itu pandangan mereka tentang masalah ini bisa diperpegangi. Kalau sebagian besar mereka berpandangan pernikahan dengan wali muhakkam tidak sah, baik menurut Hukum Islam apalagi Hukum positif, maka sudah seharusnya praktik demikian dihentikan, karena ada konsekuensi hukumnya. Tidak ada gunanya menikah dengan wali muhakkam, kalau status hukumnya tidak jelas dan meragukan. Di dalam Islam sesuatu yang halal itu jelas dan yang haram juga jelas. Namun di antara keduanya ada yang samar-samar, yang lebih baik dijauhi supaya agama tetap terjaga. Agama Islam menyuruh umatnya meninggalkan hal-hal yang meragukan, sebagaimana sabda Rasulullah saw yang artinya: Dari Amir berkata, saya mendengar Nu'man bin Basyir berkata: saya mendengar Rasulullah saw bersabda: halal itu jelas dan haram itu jelas dan di antara keduaya ada yang syubhat (samar), yang tidak diketahui oleh kebanyakan manusia. Barangsiapa menjaubi yang syubhat berarti ia memelihara agamanya, dan barangsiapa melakukan yang syubhat berarti ia merusak agamanya, seperti gembala yang menggembala di tepi jurang, yang mungkin sekali akan jatub ke dalammya (HR. alBukhari). ${ }^{74}$

Di dalam hadits lain dinyatakan yang artinya: Dari Anas ra dari Nabi saw beliau bersabda: Tinggalkan

74 al-Imam al-Bukhari, Op. cit., Jilid I, Juz 1, hlm. 19. apa yang meragukanmu dan lakukan apa yang tidak. meragukanmu (HR Ahmad). ${ }^{75}$

Jadi pasangan yang mau menikah hendaknya menjauhi pernikahan dengan wali muhakkam. Masyarakat yang tidak mengerti hukum juga hendaknya tidak menganjurkan pernikahan demikian. Begitu juga pemuka agama. kalau ada yang minta dinikahkan, hendaknya mencarikan solusinya agar pernikahan tetap dilangsungkan sesuai prosedur yang berlaku.

Apalagi menurut ulama tersebut, implikasi sosial dari pernikahan dengan wali muhakkam sangat luas dan cenderung merugikan pihak istri dan anak-anaknya kelak. Mereka tidak bisa berurusan ke pengadilan agama, tidak bisa menuntut gaji/tunjangan anak/istri/suami di tempat kerjanya, tidak bisa menuntut masalah harta, kewarisan dan perwalian, tidak bisa mendapatkan akta kelahiran anak dan banyak lagi. Jadi implikasinya tidak sebatas kesulitan mendapatkan akta kelahiran saja seperti dipahami oleh pasangan yang menikah dengan wali muhakkam.

Adanya banyak implikasi demikian, berari pernikahan dengan wali muhakam akan membawa mudarat, terutama bagi istri dan anak-anak di Kemudian hari. Agama tidak menghendaki kemudaratan demikian, hanya karena kepentingan sesaat, yaitu ingin menikah secara instan. Sebuah kaidah fikih menyatakan "Menghindari keburukan bendaknya didabulukan daripada menarik kemanfaatan". 76

Hanya saja para ulama tersebut bervariasi pendapatnya tentang solusi untuk mengatasi. Pertama, ada yang berpendaat solusinya harus tegas, yaitu pernikahan dengan wali muhakkam dinyatakan tidak sah, haram dan pelakunya dikenai sanksi penjara. Cara seperti ini sudah diterapkan di Kota Pontianak Kalimantan Barat. Cara demikian mungkin cukup efektif untuk mencegah praktik pernikahan dengan wali muhakkam. Tetapi di Kota Banjarmasin kelihatannya hal ini belum dilakukan. Dari enam pemuka agama yang biasa berperan sebagai wali muhakkam, hanya dua orang yang mengaku pernah ditegur oleh petugas KUA,

\footnotetext{
75 al-Imam Jalaluddin Abdirrahman bin Abibakar alSuyuthi, al-Jami' al-Shaghir, Juz 1, (Surabaya: Dar al-Ihya al-Kutub al-Arabiyah, tth), hlm. 15.

76 Masyfuk Zuhdi, Op. cit., hlm. 158.
} 
selebihnya tidak pernah ditegur apalagi diberi sanksi lain yang lebih tegas. Bahkan seorang responden menyatakan, pegawai KUA, PA dan Kantor Departemen Agama adalah teman-teman sekolah bahkan murid-muridnya juga. Mungkin karena itu mereka agak sungkan memberi teguran.

Sebenarnya dalam masalah hukum harus dibedakan antara sisi kemanusiaan (hubungan pertemanan) dengan keharusan menegakkan hukum. Sebaiknya ada tindakan yang lebih tegas dari pemerintah dan kepolisian sebagai pemilik kemampuan eksekusi. KUA sendiri tidak memiliki kemampuan dan aparat eksekusi. Jadi ini sangat tergantung kepada kebijakan pememrintah daerah dan aparat keamanan. Selama tidak ada tindakan tegas, dikhawatirkan praktik pernikahan dengan wali muhakkam akan terus berlangsung, entah sampai kapan baru berhenti. Dalam hal ini berlaku prinsip supply and demand, ada yang bersedia menikahkan dan ada yang minta dinikahkan. Kalau pemerintah memiliki komitmen bahwa masalah ini melanggar hukum ada sanksi nyata, kita yakin praktik demikian berangsur akan hilang.

Kedua, di antara ulama lebih menganjurkan pendekatan persuasif. Para ulama, juru dakwah, muballigh/muballighah dan instansi terkait harus lebih proaktif melakukan penyuluhan. Sering menyampaikan masalah ini dalam dakwah, ceramah dan pengajian, supaya masyarakat memiliki kesadaran hukum. Masyarakat awam masih banyak melakukan hal ini karena mereka kurang mengetahui dan buta hukum. Harus diakui, materi dakwah dan pengajian selama ini jarang sekali menyinggung persoalan wali muhakkam.

Kaitannya dengan pendekatan persuasif ini, aparat KUA hendaknya mencarikan solusi setiap ada pernikahan yang bermasalah. Pasangan peru diberikan bimbingan dan pencerahan agar mereka mengerti duduk persoalannya. Dengan bantuan KUA, mungkin masalah perwalian dalam pernikahan mereka bisa disederhanakan dan dibantu penyelesaiannya. Termasuk bantuan berupa dispensasi biaya jika pasangan yang menikah tidak mampu. Prosedur pernikahan perlu lebih disederhanakan supaya pasangan begini tidak berpikir mencari jalan pintas menikah dengan wali muhakkam.

Adanya fenomena pemuka agama berani menikahkan orang dengan wali muhakkam kelihatannya juga disebabkan mereka merasa benar dengan tindakannya. Kenyataan ini perlu melibatkan para ulama yang memiliki komptensi, yang ahli di bidang hukum Islam. Para ulama dan pemuka agama yang biasa menikahkan orang dengan wali muhakkam tersebut perlu duduk dalam satu meja, berdiskusi, berdialog bahkan berdebat untuk mempersoalkan pernikahan dengan wali muhakkam disertai solusinya. Ini penting mengingat hal demikian masih sering terjadi dan menjadi kontroversi di tengah ulama dan masyarakat. Dari sini diharapkan muncul titik terang, sehingga yang merasa keliru dapat merevisi pendirianya. Kemudian ke depan sepakat untuk memilih cara yang lebih aman dalam pandangan hukum, terutama Hukum Islam.

\section{Penutup}

Dapat disimpul bahwa pernikahan dengan wali muhakkam masih terjadi di Kota Banjarmasin. Sejumlah pasangan yang mengalami permasalahan di segi wali (wali nasab adhal, tidak ada, jauh dan berbeda agama) menghubungi pemuka agama untuk minta dinikahkan. Oleh pemuka agama mereka dinikahkan, dengan mereka sendiri berperan sebagai wali muhakkam, disaksikan para saksi. Untuk membuktikan adanya pernikahan, di antara mereka dibuatkan surat bukti sebagai dokumen pernikahan dengan stempel materai dan tanda tangan wali muhakkam, pasangan yang menikah, para saksi dan ketua RT. Para pemuka agama melakukan demikian karena beranggapan ada mazhab tertentu membolehkan pernikahan demikian ketika terbentur pada masalah perwalian serta karena keadaan darurat dan khawatir terjadi perzinaan.

Pasangan tersebut umumnya berasal dari luar daerah, berstatus janda/duda, berpendidikan relatif rendah. Mereka menikah dengan wali muhakkam karena wali nasabnya adhal, tidak ada, jauh dan sulit dihubungi serta karea berbeda agama dengan wali nasabnya. Implikasi hukum yang mereka alami belum ada sebab setelah dinikahkan, mereka merasa aman saja karena sudah dianggap sah oleh pemuka agama yang menikahkan dan oleh masyarakat. Implikasi sosial yang dirasakan baru berupa kesulitan mengurus akta kelahiran anak yang dilahirkan karena ketiadaan buku nikah. Risiko ini sudah diketahui dari awal sebelum menikah. Mereka belum menyadari risiko-risiko lainnya yang sangat merugikan terutama bagi pihak 
istri dan anak. Sebagian dari pasangan berencana meresmikan pernikahan mereka di KUA jika memungkinkan agar memiliki buku nikah.

Para ulama di Kota Banjarmasin umumnya berpandangan pernikahan dengan wali muhakkam tidak sah, karena hanya sultan saja yang berwenang menjadi wali hakim bagi wanita yang mengalami masalah dalam hal wali. Sebagian kecil ulama mengakui pernikahan dengan wali muhakkam dibolehkan oleh sementara mazhab namun hanya dalam kondisi darurat misalnya tidak ada sultan dan dalam keadaan terisiolasi di laut atau di hutan yang tidak memungkinkan berkomunikasi dengan masyarakat. Sekarang kondisi darurat demikian tidak ada lagi, karena sultan (walihakim) ada di mana-mana. Pernikahan demikian menurut ulama banyak mudharatnya karenanya harus dihindari. Sebagai solusinya ditawarkan dua alternatif; pertama, pendekatan hukum dengan menganggap tidak sah pernikahan dengan wali muhakkam tersebut dan menjatuhkan sanksi penjara bagi pelakunya sebagaimana sudah diberlakukan di Kota Pontianak Kalimantan Barat. Solusi begini ternyata belum dilakukan di kota Banjarmasin, bahkan pemerintah seperti tetap membiarkannya. Satu sisi melarang, tetapi pelanggarnya tidak dihukum. Kedua, pendekatan persuasif, dengan aktif memberi penyuluhan dan dakwah kepada masyarakat untuk menanamkan kesadaran hukum. KUA perlu proaktif membantu pasangan yang ingin menikah tapi bermasalah dalam hal wali. Sesama ulama dan pemuka agama perlu duduk satu meja untuk mengkaji dan mencarikan solusi agar pernikahan dengan wali muhakkam tidak terjadi lagi. Pendekatan kedua ini belum dilakukan, sehingga pemuka agama dan pasangan yang menikah tetap merasa aman mempraktikkan pernikahan dengan wali muhakkam.

Menurut Hukum Islam pernikahan dengan wali muhakkam tidak sah, sebab hanya sultan/pemerintah dalam hal ini Pengadilan Agama dan KUA yang berhak sebagai wali hakim bagi wanita yang bermasalah dalam hal wali nikah. Hukum Islam hanya membolehkan wali muhakkam dalam kondisi darurat di mana tidak ada wali hakim dan pasangan calon suami istri terisolasi dari kehidupan dan tidak dapat berkomunikasi dengan masyarakat. Menurut Hukum Positif, pernikahan dengan wali muhakkam juga tidak sah sebab dilaksanakan di luar aturan dan prosedur yang digariskan oleh perundang-undangan, khususnya Undang-Undang Perkawinan dan Kompilasi Hukum Islam.

Meminimalisasi pernikahan dengan wali muhakkam, disarankan agar pemuka agama yang biasa menikahkan pasangan suami istri dengan wali muhakkam meninjau ulang tindakannya, sebab pernikahan demikian sangat diragukan keabsahan hukumnya baik menurut Hukum Islam apalagi Hukum Positif, serta banyak membawa dampak yang merugikan bagi suami istri dan anak-anaknya. Pasangan yang akan menikah dan mengalami masalah di segi wali, hendaknya tetap berusaha maksimal untuk menikah secara resmi di KUA dengan terlebih dahulu berkonsultasi dan minta bantuan melalui KUA dan Pengadilan Agama. Setelah mengetahui duduk persoalannya tidak mustahil mereka akan dibantu dengan kemudahan dan dispensasi lainnya sehingga pernikahannya dapat dilakukan sesuai dengan prosedur. Langsung menikah dengan wali muhakkam hendaknya dihindari sebab dasar dan alasan hukumnya sangat lemah dan masih ada peluang lain yang bisa digunakan. Instansi dan aparat pemerintah terkait hendaknya dapat menegakkan hukum dengan menegaskan ketidakabsahan pernikahan wali muhakkam disertai sanksi hukum yang jelas. Ulama dan pemuka agama hendaknya proaktif memberikan dakwah, ceramah dan penyuluhan guna menanamkan kesadaran hukum di masyarakat supaya tidak terjadi praktik pelanggaran dalam tatacara pernikahan. Dialog dan musyawarah untuk mengkaji masalah dan implikasi pernikahan dengan wali muhakkam penting dilakukan supaya tumbuh kesadaran untuk tidak lagi melangsungkan pernikahan demikian. Majelis Ulama Indonesia (MUI) hendaknya mengeluarkan fatwa yang melarang pernikahan dengan wali muhakkam, sebab landasan hukumnya sangat lemah dan dapat berdampak pada longgarnya ikatan perkawinan dan terabaikannya hak-hak istri dan anak.

\section{Daftar Pustaka}

Abdurrahman, Kompilasi Hukum Islam di Indonesia, (Jakarta: Akademika Presssindo, 1990).

Ahmad Husairi, al-Nikah al-Qadhaya al-Mutaaliqah Bih, (Kairo: Maktabah Kuliah al-Azhar, 1968).

Al-Alawi, Said Abdurrahman, Bughyah alMustarsyidin, (Beirut; Dar al-Fikr, tth). 
Al-Anshari, Syaikh al-Islam Abi Zakariya Yahya, Fath al-Wabhab, (Surabaya: Al-Hidayah, tth).

Al-Asqalani, Al Imam Ibn Hajar, Bulugh al-Maram fi Adillat al-Ahkam, (Surabaya: Dar al-Ihya alKutub, tth).

Al-Bukhari, Al Imam Abi Abdillah Muhammad bin Ismail bin Ibrahim, Shahih al-Bukhari, (Beirut: Dar al-Fikr,1401 H).

Departemen P \& K RI, Kamus Besar Bahasa Indonesia, (Jakarta: Nalai Pustaka, 1990).

Al-Dimyati, Said Bakry, Khasyiah I'anath al-Thalibin, (Beirut: Dar al-Fikr, tth).

Alhamdani, HAS., Risalab Nikah, (Jakarta: Pustaka Amani,1989).

Ibnu Rusyd, Bidayah al-Mujtabid, (Beirut: Dar alFikr, tth).

Al-Jaziri, Abdurrahman, Kitab al-Figh 'ala alMazabib al-Arba'ah, (Beirut: Dar al-Kitab, th).

Imam Musbikin, Qawaid al-Fighiyah, (Jakarta: Raja Grafindo Persada, 2001).

Imam Suyuthi, Al-Asybah wa al-Nazhair, (Beirut: Dar al-Kitab, 1407 H).

Al-Jamal, Ibrahim Muhammad, Figh al-Mar'ah alShalihah, (Semarang: al-Syifa, 1989).

Departemen Agama RI, Alquran dan Terjemahnya, (Jakarta: Proyek Pengadaan Kitab Suci Alquran, 1984/1985).

$\longrightarrow$ Pedoman Pegawai Pencatat Nikah dan Pembantu Pegawai Pencatat Nikah,

(Jakarta: Proyek Peningkatan Sarana Keagamaan Islam, Zakat dan Wakaf, 1995/1996).

Al-Husaini, Usman bin Abdullah bin Aqil bin Yahya al-Alawi, al-Qawanin al-Syar'iyyah, (Surabaya: Syirkah Maktabah wa Mathba'ah Salim Nabhan wa Auladuh, th).

Al-Jaziry, al-Syeikh Abdurrahman, Kitab al-Fiqh 'Ala al-Mazabib al-Arba'ah, (Beirut: Dar alFikr, tth).

Al-Kahlani, Al Imam Muhammad Ismail, Subul alSalam, (Beirut; Dar al-Fikr,1412 H).

Majelis Ulama Indonesia (MUI), Himpunan Fatwa MUI, (Jkarta; Departemen Agama RI, 2003).

Al-Malibary, Syeikh Zainuddin bin Abdul Aziz, Fathul Mu'in, (Kudus: Menara, 1983).

Al-Maraghi, Syaikh Ahmad Musthafa, Tafsir alMaraghi, (Kairo: Dar al-Musthafa al-Babi alHalabi, 1389 H).
Al-Qardhawi, Abdullah Yusuf, Halal dan Haram dalam Islam, Alih bahasa Muammal Hamidy, (Surabaya: Bina Ilmu, 1990).

Al-Qusyairi, al Imam Abi al-Husain Muslim bin alHajjaj, Shabih Muslim, (Beirut: Dar al-Fikr, $1401 \mathrm{H})$.

Sayyid Sabiq, al-Syaikh, Fiqh al-Sunnah, (Beirut: Dar al-Fikr, 1403H). Fikib Sunnah 7, alih bahasa Moh.Thalib, (Bandung: Almaarif, 1987).

Al-Sijistani, Al-Imam Abi Daud Sulaiman ibn alAsy'ats, Sunan Abi Daud, (Surabaya: Maktabah Dahlan, tth).

Soesilo, R., Kitab Undang-Undang Hukum Pidana Serta Komentar-komentarmya, (Bogor: Politeia, 1992).

Suryabrata, Sumadi, Metodologi Penelitian, (Jakarta: Raja Grafindo Persada,1997).

Al-Syafi'i, Al Imam Muhammad Idris, Al-Umm, (Beirut: Dar al-Fikr, tth).

Al-Syaukani, al-Imam Muhammad, Nailul Authar, Juz 6, (Semarang: asy-Syifa, 1994).

Syuaisi, Syaikh Hafizh Ali, Kado Pernikahan, Alih bahasa Abdul Rosyad Siddiq, (Jakarta: Pustaka Alkautsar, 2005).

Syukur, M. Asywadie, Wali Hakim Menurut Fikih Islam dan Kompilasi Hukum Islam di Indonesia, (Banjarmasin: Majelis Ulama Indonesia Kota Banjarmasin, 2003).

Tim Penyusun, Pedoman Penulisan Tesis Program Pascasarjana LAIN Antasari, (Banjarmasin: IAIN Antasari, 2006).

Al-Tirmidzi, al-Imam Abi Isa Muhammad bin Isa bin Tsaurah, Sunan al-Tirmidri, (Surabaya: Maktabah Dahlan, tth).

Yunus, Mahmud, Kamus Arab Indonesia, Jakarta: Yayasan Penyelenggara Penerjemah dan Penafsir Alquran, 1973).

Al-Zarqa, Syaikh Ahmad bin Muhammad, Syarah al-Qawaid al-Fiqhiyah, (Beirut: Dar al-Fikr, $1407 \mathrm{H})$.

Zuhdi, Masyfuk, Masail Fiqhiyah, (Jakarta: Haji Masagung, 1996) 